تطوير فاعلية أداء حركات القدمين وسرعة انطلاق الكرة في الضربات

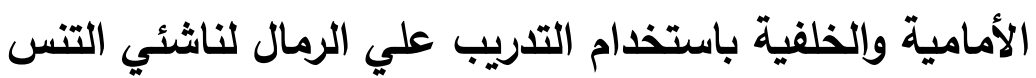

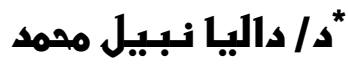

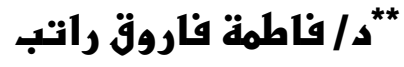
المقدمة ومشكلة البحث : المثئ

يعد الاهتمام بالناشئين ضرورة ملحة باعتبارهم يشكلون القاعدة العريضة

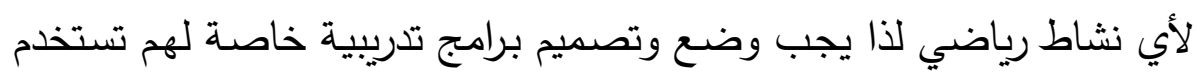
احدث الوسائل والطرق العلمية ضمانا للوصول بهم للمستويات العالية.

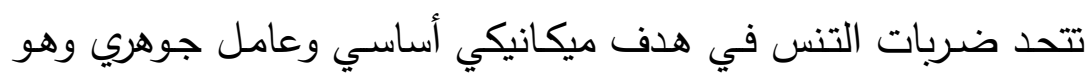

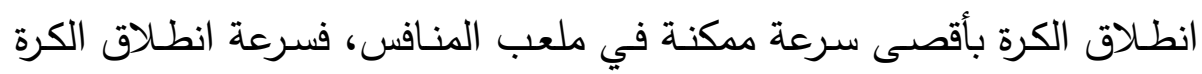

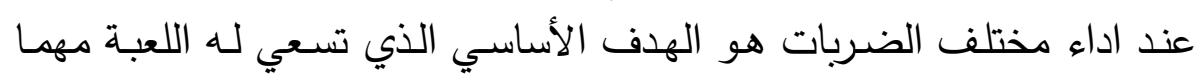

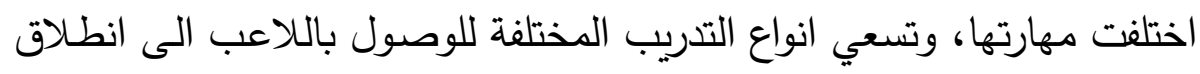

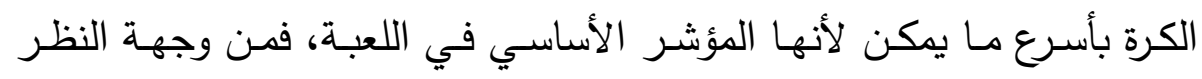

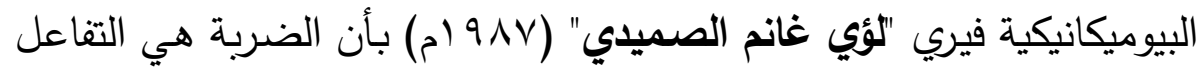

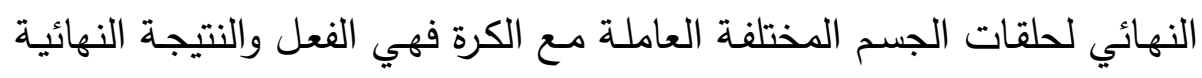

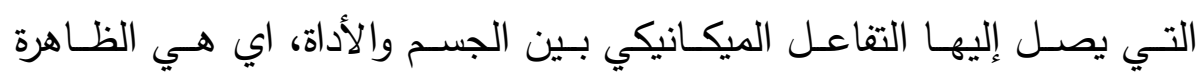

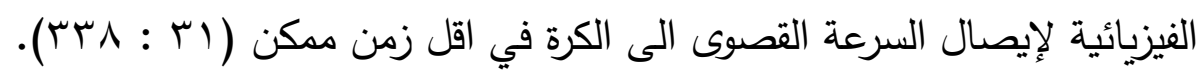

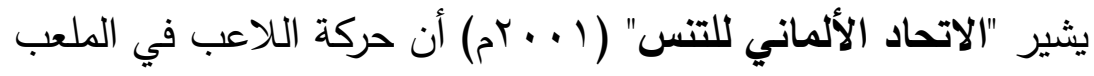

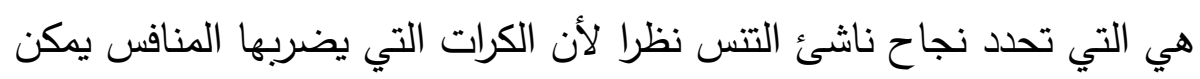

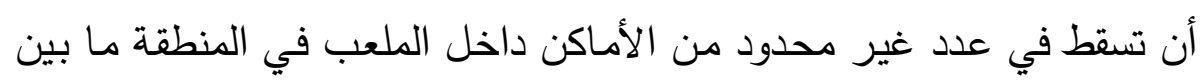

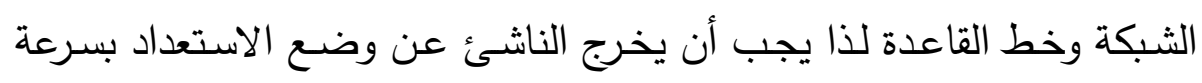

" عضو منحة سابق للحصول على درجة الماجستير والدكتوراه قسم علوم الحركة بالرياضية

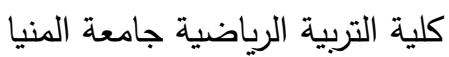
" مدرس بقسم الرياضات الجماعية والعاب المضرب بكلية التربية الرياضية جامعة المنيا مجلة أسيوط لعلوم وفنون التربية الرياضية الرياضية 
للوصـول المبكر للكرة واتخـاذ الوضـع المناسـب لضـربها بشكل جيد ثم العودة

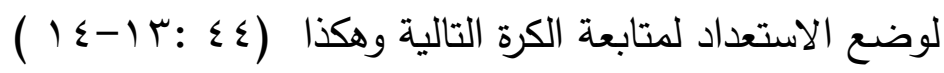

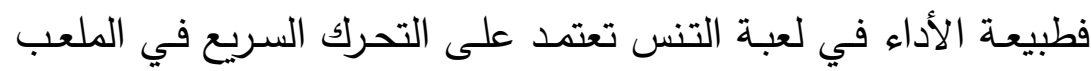

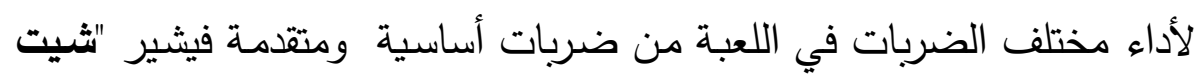
ميرفي" (99191م) الى تقسيم الضربات الأساسية في التس الى ضربات أمامية

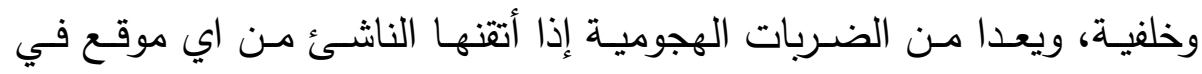
الملعب وهذا بدوره بيفرض على اللعبة قدرات بدنية خاصة لإتقان التحرك داخل

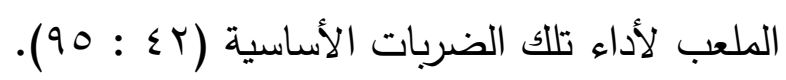

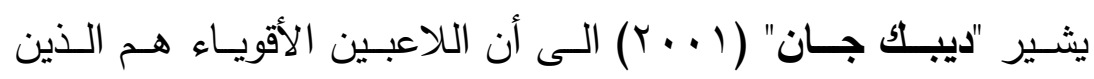
يستطيعون الإسراع في الوصول للكرة بوقت كافي ووضـع مناسب يمكنهم من

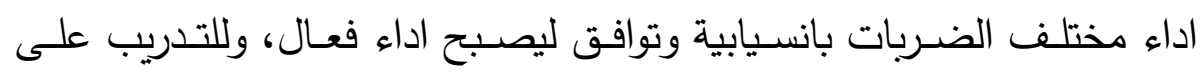
حركات القدمين يتم تحسين الجري بخطوات قصيرة وسريعة مع الإبطاء قبل الوصول للكرة بمسافة صغيرة للمساعدة في تغيير وضع الجسم للوضع الجانبي لضرب الكرة مع ملامسة القدمان الارض لحظة الضرب لإعطاء الضربة المزيد

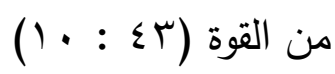

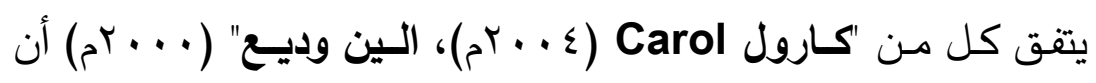

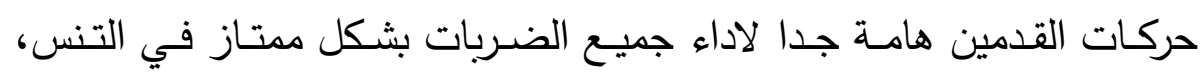
ويشير أن الناشئ يجب أن يتحرك بسرعة وفعالية داخل الملعب لاداء ضرباته هاته في وضعية مناسبة وبشكل صحيح، فمشكلة العديد من لاعبي التنس تكمن في

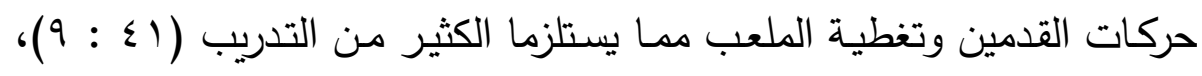

(1) 6r:9)

يري "الاتحاد الأمريكي لتنس المحترفين USPTA" (0 . . ب) انه يجب الاهتمـام بوضـع البـرامج التدريبيـة المنظمـة بشـكل علمي لتحسين وتطـوير 
المهارات المختلفة وخاصة حركات القدمين لأنها عملية متتابعة ومستمرة خلال جميع مراحل الأداء المختلفة في رياضة التنس.

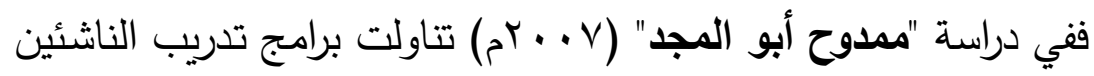

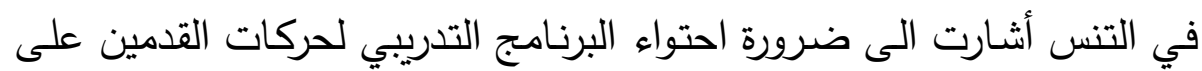

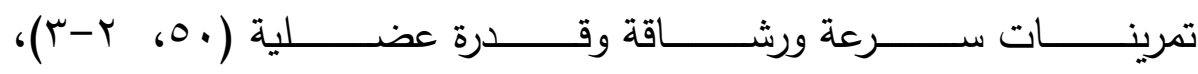
. ( $\leqslant \wedge: 乏 \cdot)$

يؤكد العديد من خبراء التنس أن السرعة تعتبر احد المؤشرات الرئيسية

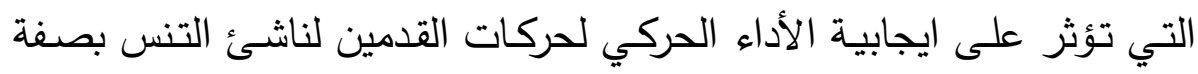

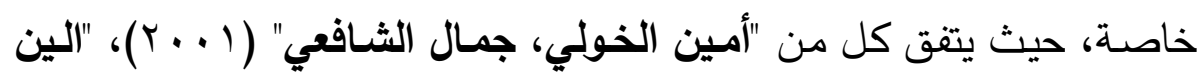

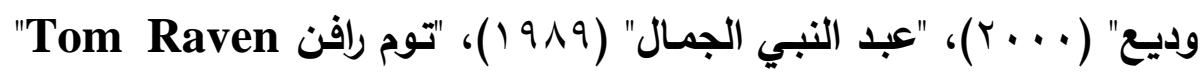
(9VV)

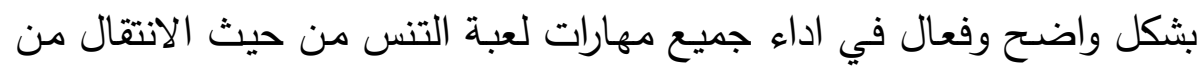

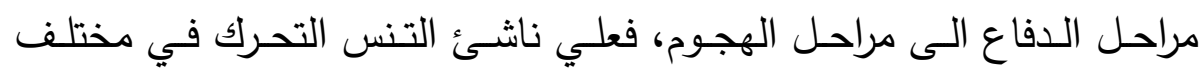

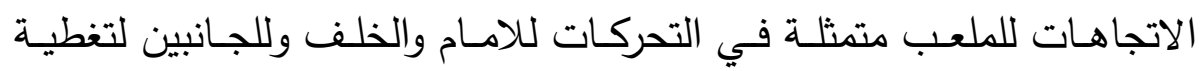

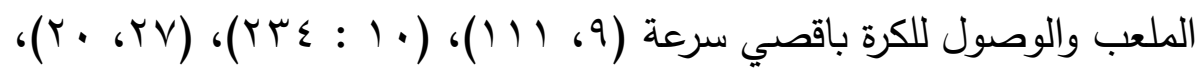
(07، . . ، 69)

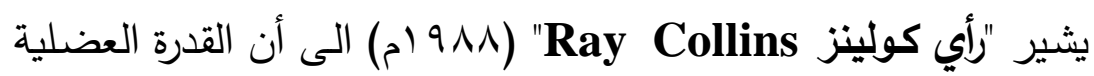

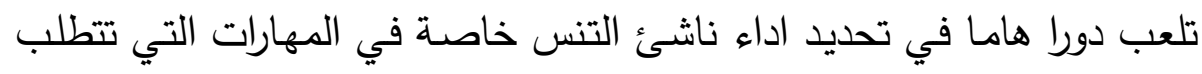

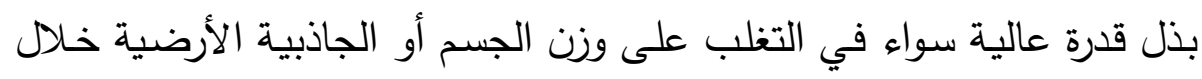

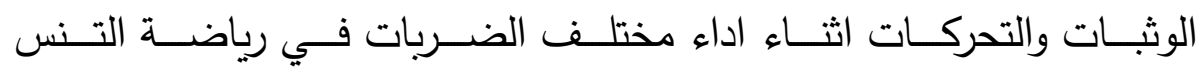

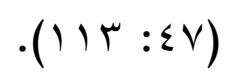

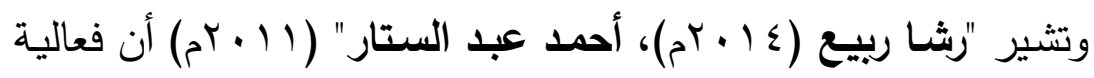

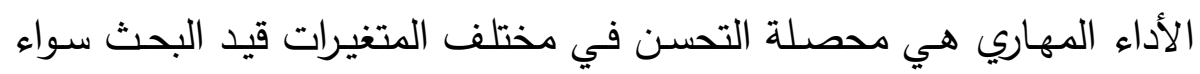


أكانت المتغيرات بدنية أو مهاريـة أو ميكانيكية أو فسيولوجية للاعبي النشـاط

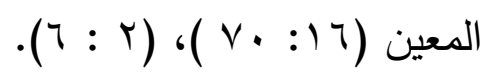

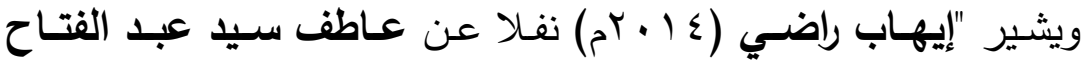

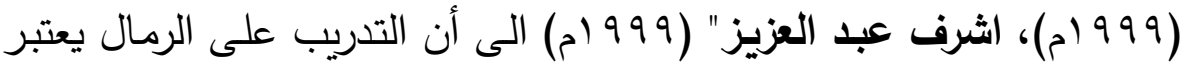

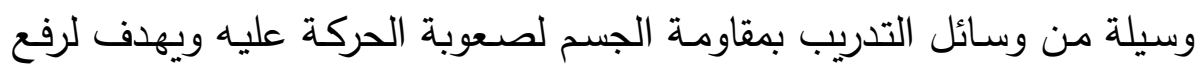

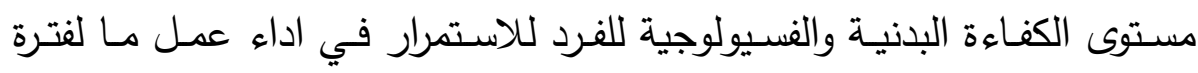

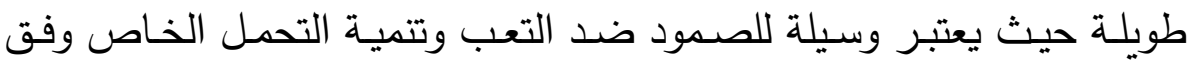
للنشاط التخصصي لرفع مستوى الأداء المهاري (11 (1) :10).

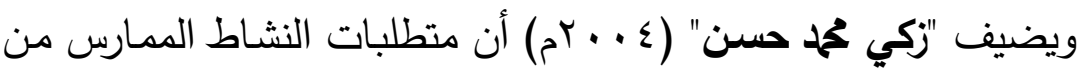

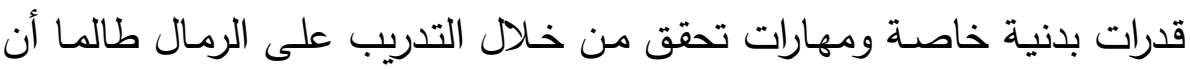

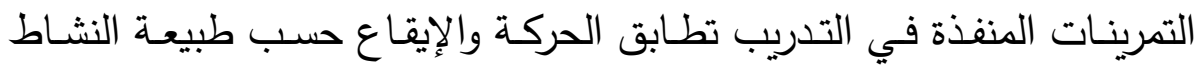

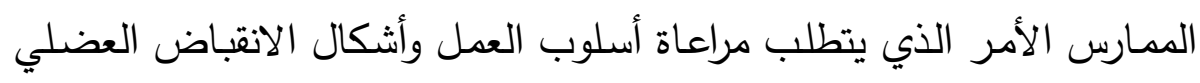
( r Y : IV)

وتري الباحثتان طبقا لما أشـار إليه العديد من العلماء أن هذه المرحلة

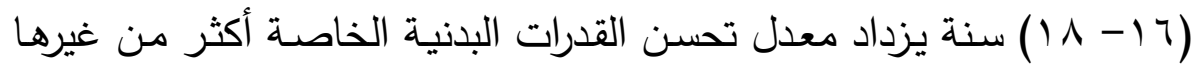

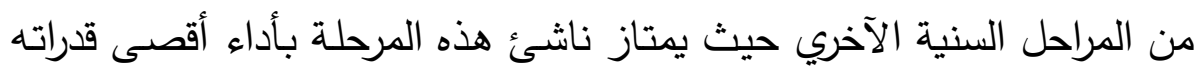

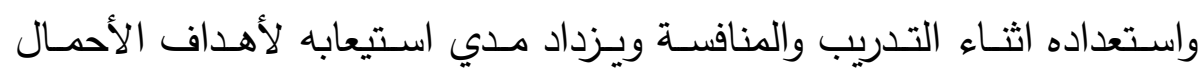
التدريبية ويتكيف معها أسـرع، ويتميز بنمو صفاته البدنية المرتبطة بـالأداء

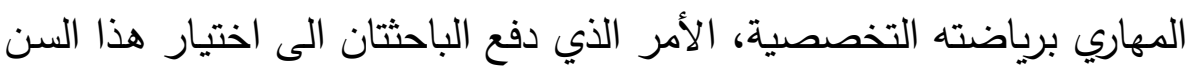
لإجراء الدراسة عليه.

وقد لاحظت الباحثتان من خلال عملهما كمدربتان ومعاونتان في تدريس

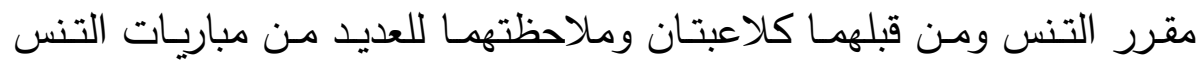
المحلية والدولية أن حركات القدمين للجانب سواء لليمين أو لليسار اي الكرات

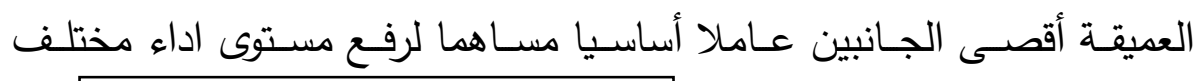


الضـربات في التنس وتحتل النصـيب الأكبر مـن تحركـات اللاعبين خـلال

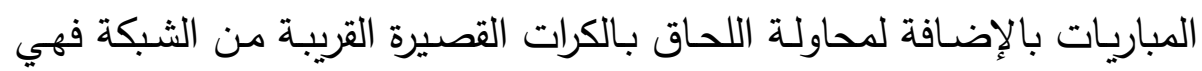

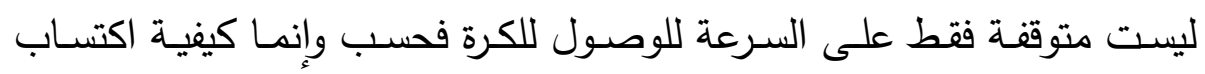

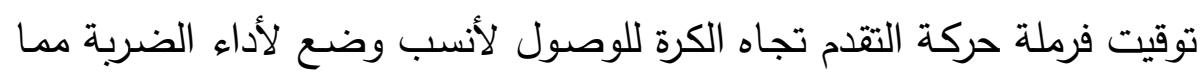

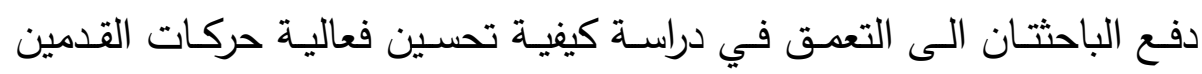
للناشئين (7 ( - 1 1) والتعرف على تأثير التدريب على الرمال على فاعلية اداء

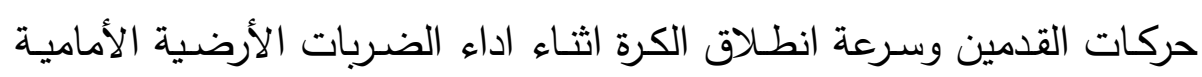

والخلفية.

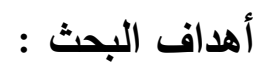

1- تصميم برنامج تدريبي لتطوير فعالية أداء حركات القدمين وسرعة انطلاق

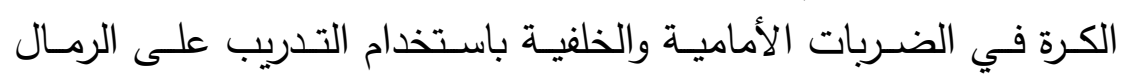

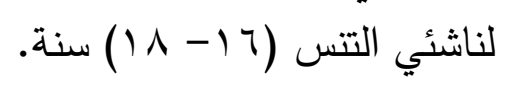

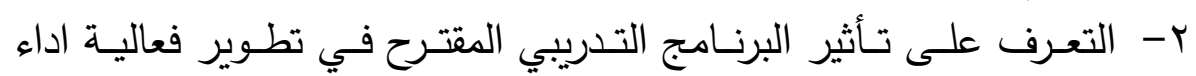

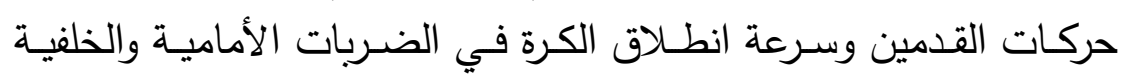
باستخدام التدريب على الرمال لناشئي التنس (7 ( - م 1) سنة.

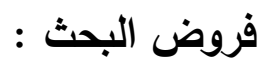

ا - للبرنـامج التدريبي المقترح تأثير ايجابي في تطوير فعاليـة اداء حركات

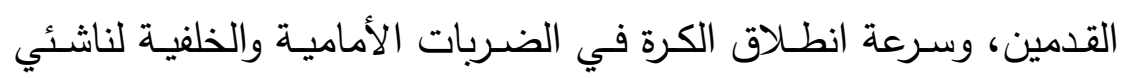

$$
\begin{aligned}
& \text { التس (T 1 - 1 1) سنة. } \\
& \text { مصطلحات البحث : }
\end{aligned}
$$

- مركات القدمين Foot work.

هي جميع التحركات التي يقوم بها الناشئ اثناء المباراة لاستقبال الكرة

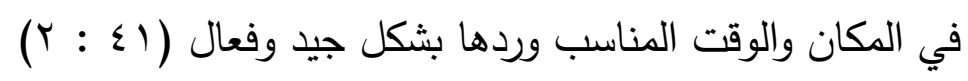




\section{الناشئ Junior.}

هو كل من لله حق الاشتراك في بطولات الجمهوريـة تحت (·r) سنة

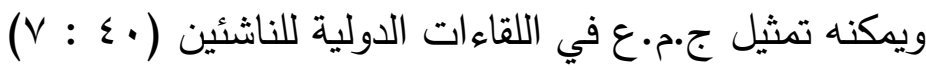

التدريب على الرمال

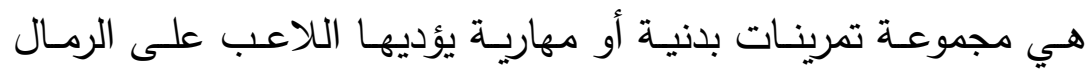
باسـتخدام وزن الجسـم كمقاومـة بهدف تحقيق اكبـر كفـاءة ممكنـة مـن القدرة

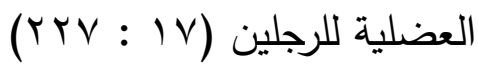
الاراسات السابقة:

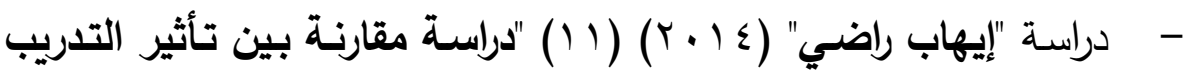
على الرمال والتدريب في الماء على القدرات البدنية الخاصـة والمستوى الرقمي لمتسـابقي · 1 ام حواجز بهدف مقارنـة تأثير كل من التدريب

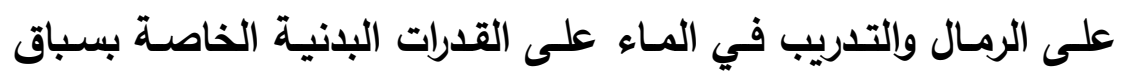

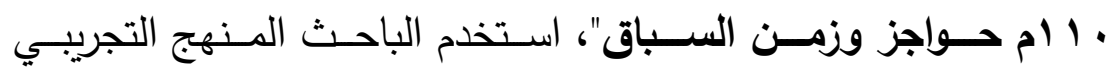

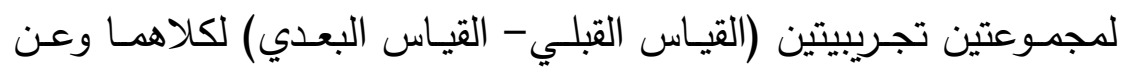
العينة فكان قوامها (Y ( ) لاعب، وكانت أهم النتائج أن تدريبات كلاهما قد

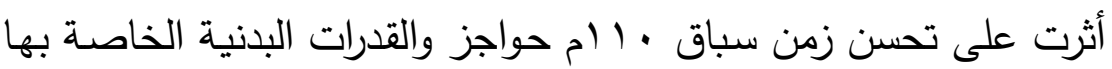
إلا أن تدريبات الوسط المائي قد سـلت تأثيرا اكبر على المتغيرات قيد البحث.

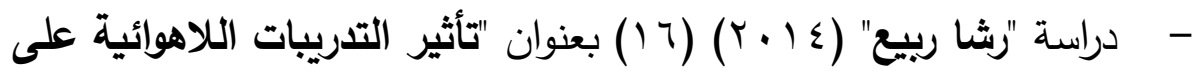
الخلايا الجذعية وفعالية اداء حركات القدمين لناشئات المبارزة"، بهدف التعرف على تأثير التدريبات اللاهوائية على الخلايـا الجذعيـة وفعالية

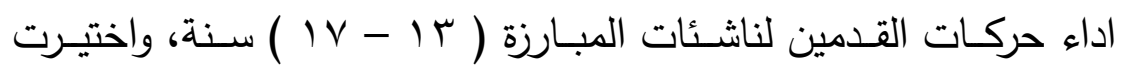
العينة بعدد (YT) مبارزة من ناشئات نـادي المعادي، واستخدمت الدراسـة المنهج التجريبي لمجموعتين ( القياس القبلي- البعدي) كلاهمـا، وكانت مجلة أسيوط لعلوم وفنون التربية الرياضية 
مـن أهـ النتائج أن البرنـامج التـدربي المقترح للمرحلـة السـية أدى إلـي تحسن كبير في المتغير الفسيولوجي قيد الدراسة وأيضا في المتغير البدني

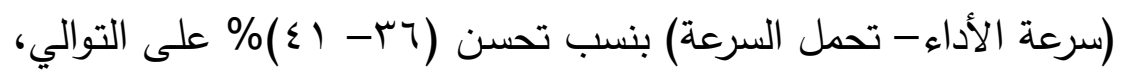
والى زيادة في المتغير المهاري (فعالية أداء حركات القدمين) بنسبة تحسن لتهن ( (ب)\% في الاختبارات المهارية قيد البحث. 


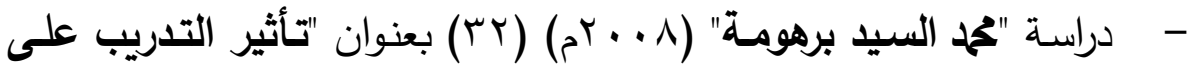

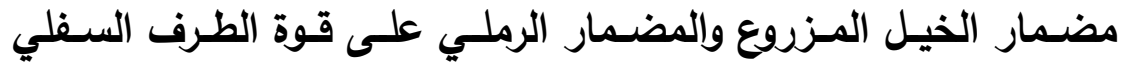

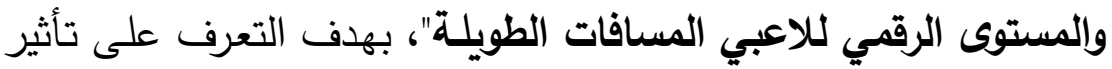

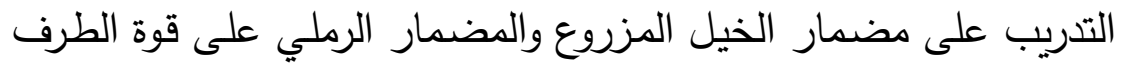

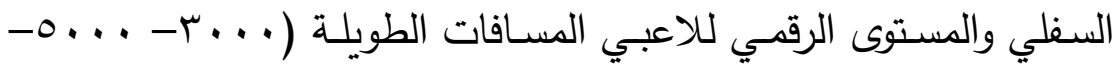

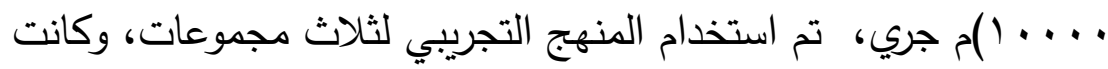

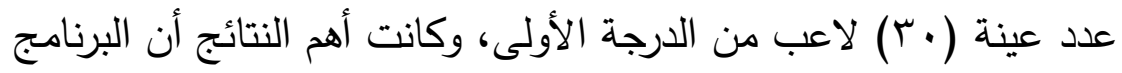

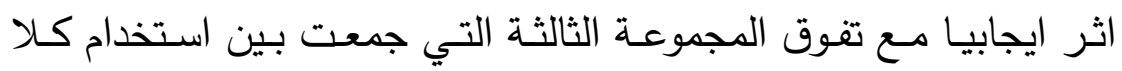
المضمارين لصالح القياس البعدي. ( …V) "S. fironi , F Martino \& V Vastagnal" دراسة -

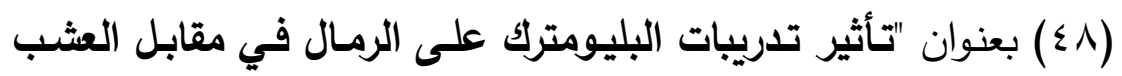

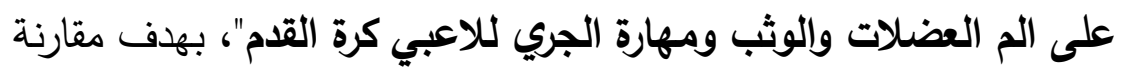

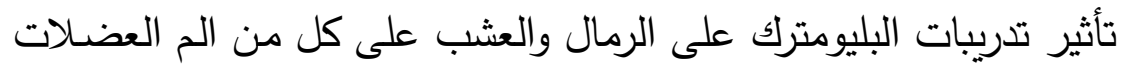

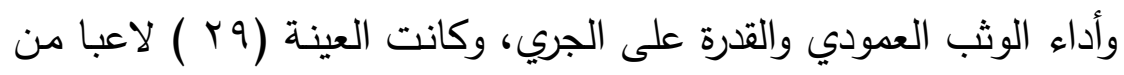

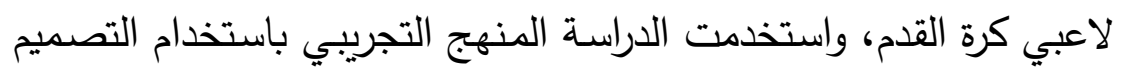

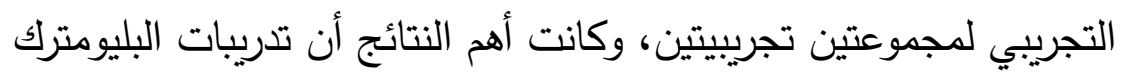

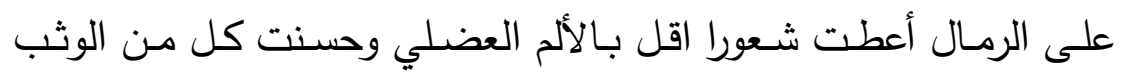

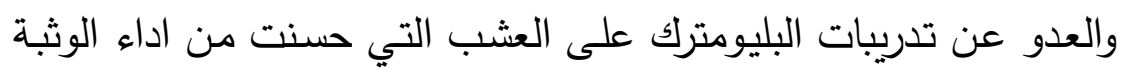
المضادة للاعبي كرة القدم.

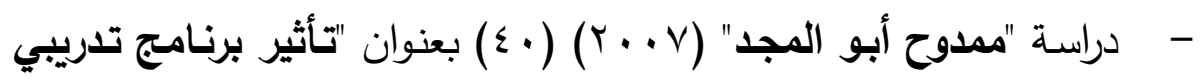

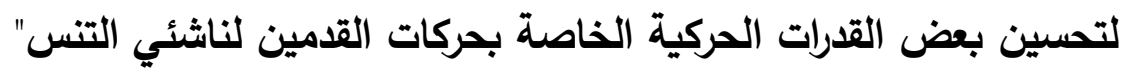

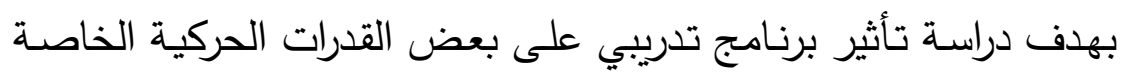

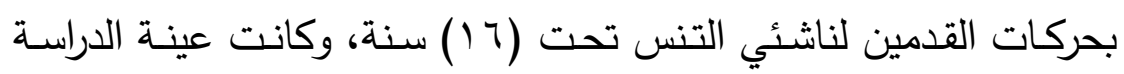

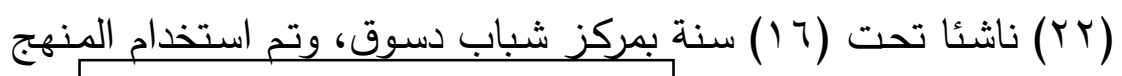
مجلة أسيوط لعلوم وفنـوز التربية الرياضية 
التجريبي في هذه الدراسـة، وكانت أهم النتائج أن البرنـامج التـدريبي

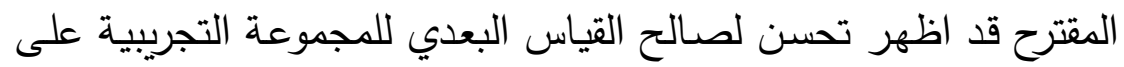
القدرات الحركية الخاصة بحركات القدمين لناشئي التنس.

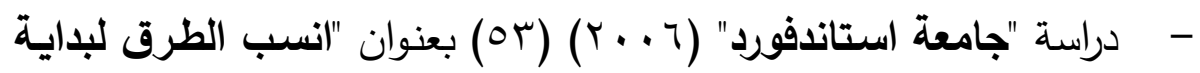

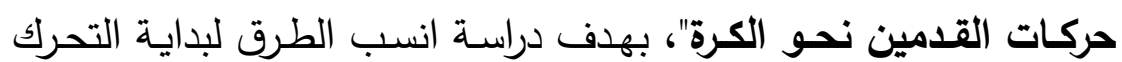

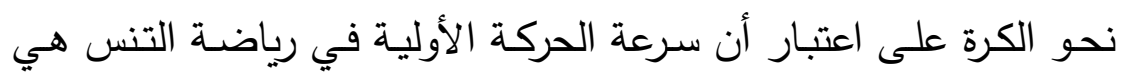

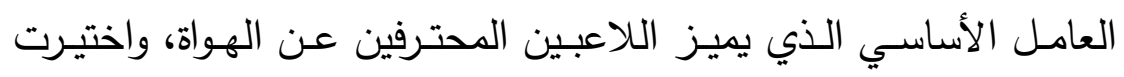

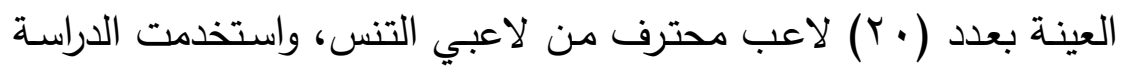

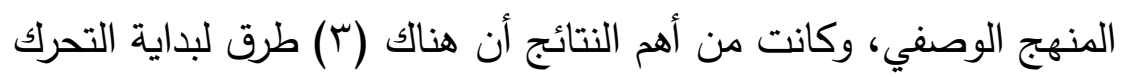
نحو الكرة خطوة طعن بخارج القدم في اتجاه الكرة، وخطوة دوران مفصل

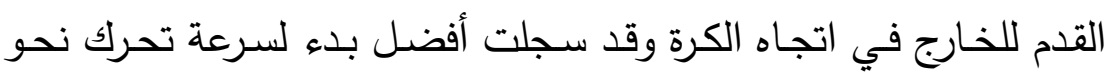
الكرة، وخطوة جذب القدم القريبة من الكرة اتجاه مضاد لاتجاه الكرة.

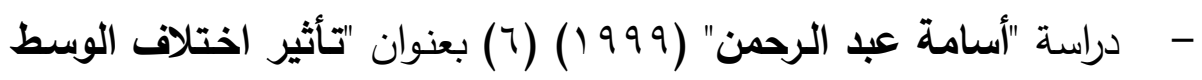

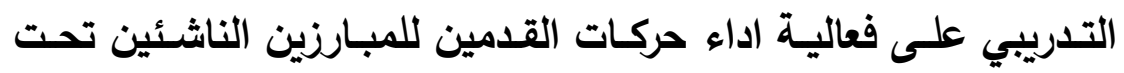

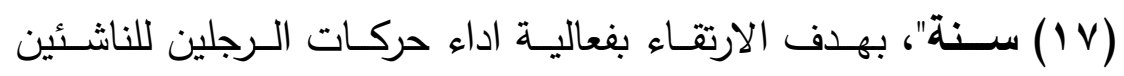

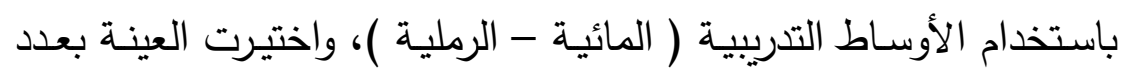

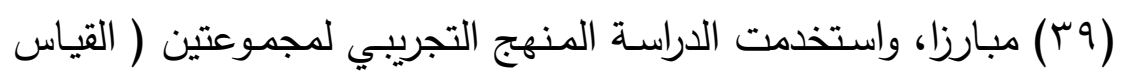

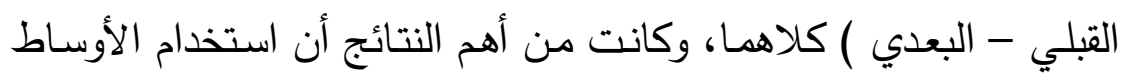

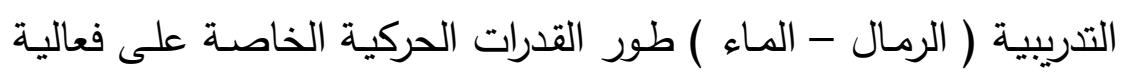
اداء حركات القدمين للمبارزين الناشئين. إجراءات البحث : أبحث

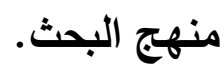

استخدمت الباحثتان المنهج التجريبي لمجموعة واحدة (القياس القبلي- 
تمثل مجتمع البحث في ناشئين نادي المنيا الرياضي للتنس (7 ( - 1 1) سنة، وتم اختيار العينة عمديا من مجتمع البحث وعددهم ( • () ناشئين وهم المشاركين فى بطولات الجمهورية والمقيدين بسجلات الاتحاد المصري للتنس.

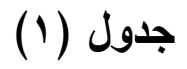
التوصيف الإحصائي لبيانات عينة البحث

\begin{tabular}{|c|c|c|c|c|}
\hline $\begin{array}{l}\text { معالنواء } \\
\text { مالتواء }\end{array}$ & المعبارى الانـمراف & الوسيط & المنتو سبط & المتغيرات \\
\hline $1,9 \wedge 7$ & $\cdot, \vee 00$ & $17, \cdots$ & $17,0 \ldots$ & العمر /السنة \\
\hline $1, \cdot \leq r$ & $0, \varepsilon \cdot q$ & 17 & 171,11 & الطول/سم \\
\hline$\cdot, 9 \wedge r$ & $\varepsilon, \cdot V$. & or,... & $00, \ldots$ & الوزن / كجم \\
\hline ס ס & $\cdot, \Lambda \backslash V$ & $\Lambda, \cdots$ & $\Lambda, 0$ & العمر التدرببى/السنة \\
\hline
\end{tabular}

ا - المجـال المكـاني : قامـت الباحثتـان بتطبيـق البرنـامج وكافـة الاختبـارات والقياسات بمجمع ملاعب التس بنادي المنيا الرياضي. r- المجال الزماني : قامت الباحثتان بتطبيق البرنامج التدريبي المقترح لمدة

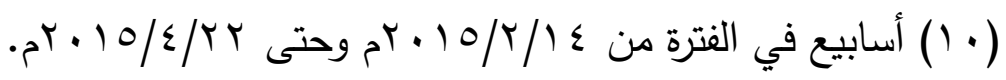
أدوات جمع البيانات:

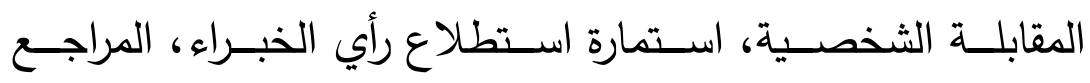

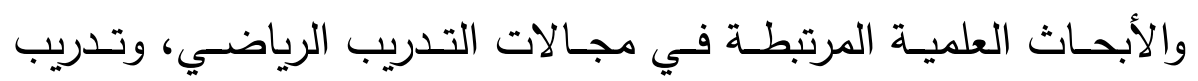
للناشئين، التدريب على الرمال، والتس لتحديد : لتحابه

(1) عناصر البرنامـ التدريبي المقترح بما يتلاءم مع طبيعة الدراسـة وعينة البحث مرفق رقم (Y) وكانت النتائج المستخلصة كالتالي :

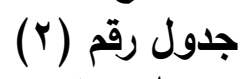

النسب المئوية لأراء الخبراء حول عناصر البرنامج التدريبي المقترح،

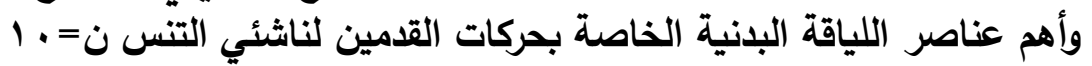




\begin{tabular}{|c|c|c|c|}
\hline نسبة الاتفاز & رأي الفبراء & عنـاصر البرنـامج & م \\
\hline$\% 9$. & (· · ( ) أسابيع & مدة البرنامج & 1 \\
\hline$\% q$. & القدرة العضلية للرجلين & \multirow{3}{*}{ أهم عناصر اللياقة البدنية الخاصة } & \multirow{3}{*}{ r } \\
\hline$\% \wedge$. & الرشاقة & & \\
\hline$\% 1 \ldots$ & السرعة & & \\
\hline$\% 1 \ldots$ & ق & زمن الوحدة التدريبية & r \\
\hline$\% 1 \ldots$ & (r) وحدات & عدد الوحدات التدريبية في الأسبوع & \\
\hline$\% \wedge$. & $(r: 1) \cdot(1: 1)$ & تشكيل وحدة التدريب (ناشئين) & \\
\hline$\% 1 \ldots$ & التدريب الفتري مرتفع الشدة & طريقة التدريب المستخدمة & 7 \\
\hline$\% 1 \ldots$ & متوسط - أقصي- عالي & الأحمال التدريبية & V \\
\hline
\end{tabular}

(Y) أهم الاختبارات البدنية والمهارية مرفق رقم (r)، وكانت النتائج كالتالي (r)

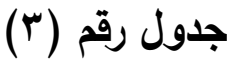

النسب المئوية لأراء الخبراء حول أهم الاختبارات البدنية الخاصة بحركات

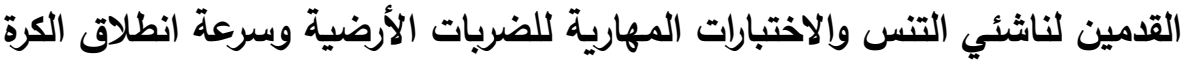

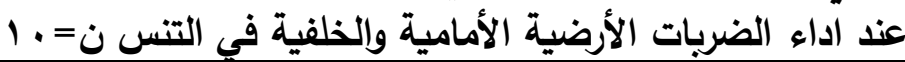

\begin{tabular}{|c|c|c|c|c|c|}
\hline ناسبة & وحدة القياس & اسلم الاذتبــــــــــار & المفة & المتنغير & م \\
\hline$\% 9$. & سم & الوثب العمودي لسارجنت & \multirow{3}{*}{ عضلية } & \multirow{7}{*}{ الاختبارات البدنية } & 1 \\
\hline$\% 1 \ldots$ & ماث & (Y)حجلات يمين & & & r \\
\hline$\% 1 \ldots$ & ماث & (ب) حجلات يسار & & & r \\
\hline$\% 1 \ldots$ & ث & سرعة تحرك القدمين بالجري يمين & \multirow{4}{*}{ 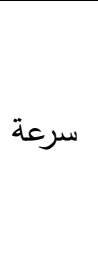 } & & $\varepsilon$ \\
\hline$\% 1 \ldots$ & ث & سرعة تحرك القدمين بالجري يسار & & & 0 \\
\hline$\% \wedge$ & ث & سرعة تحرك القدمين بالزحلقة يمين & & & 7 \\
\hline$\% \wedge$. & ث & سرعة تحرك القدمين بالزحلقة يسار & & & V \\
\hline
\end{tabular}


$v V$.

\begin{tabular}{|c|c|c|c|c|c|}
\hline$\% 9$. & ث & سرعة تحرك القدمين بالجري للامام & & & $\wedge$ \\
\hline$\% \wedge$. & ث & عدو r r م في خط مستقيم & & & 9 \\
\hline$\% 1 \ldots$ & ث & العنكبوتي & \multirow{3}{*}{ 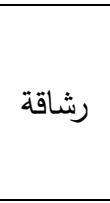 } & & 1. \\
\hline$\% 9$. & ث & 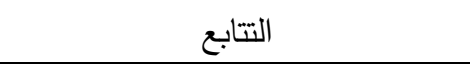 & & & 11 \\
\hline$\% \wedge$. & ث & الجري الزجزاجي & & & IT \\
\hline$\% 1 \ldots$ & عدد & داير للضربات الأرضية الأمامية & \multirow{2}{*}{ وسرة } & \multirow{2}{*}{ الاختبارات } & ir \\
\hline$\% 1 \ldots$ & 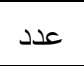 & داير للضربات الأرضية الخلفية & & & $1 \varepsilon$ \\
\hline$\% 1 \ldots$ & ماث & سرعة انطلاق الكرة (الضربة الأمامية) & \multirow{2}{*}{ سرعة } & \multirow{2}{*}{ متغيرات } & 10 \\
\hline$\% 1 \ldots$ & 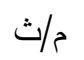 & سرعة انطلاق الكرة (الضربة الخلفية) & & & 17 \\
\hline
\end{tabular}

- التصوير بالفيديو والتحليل الحركي :

عدد (r) كاميرا تصوير فيديو ( أمامية - جانبية يمني - جانبية يسرى)

ماركة sony م مللي تردد هY كادر / ث - مرفق رقم (V) موضع الكاميرات أثتاء التصـوير ، عدد (r) حامل ثلاثي، علامـات ضـابطة وإرشـادية، برنـامج

تحليل حركي (Simi Motion Analysis)، Monitor،

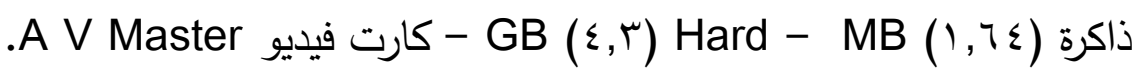

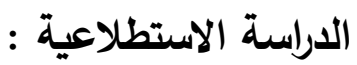

قامت الباحثتان بإجراء الدراسة الاستطلاعية على عينة من ناشئي نادي

المنيا الرياضـي للتنس (T ( - 1 1) سـنة ولم تشترك هذه العينـة في التطبيق

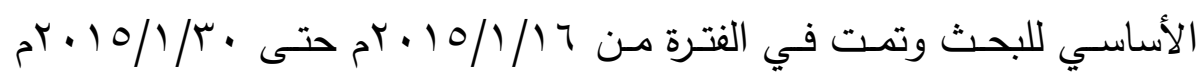

$$
\text { وكان هدف هذه الدراسة : }
$$

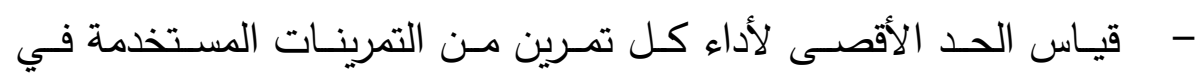
البرنامج وذلك لتحديد شدة الحمل لكل لاعب على حدة خلال الوحدات

التدريبية لمراعاة الفروق الفردية بين الناشئين. 
- - تربهة وحدة تدريبية من البرنامج التدريبي قيد البحث، تم تتظيم التدريب بعد عمل هذه التجربـة الاستطلاعية لتحديد فترات الراحة البينية بعد كل

$$
\text { حمل (أقصي- عال- متوسط). }
$$

- إجـراء بعـض الاختبـارات لضـمان حسـن سـير البرنـامج لتحقيـق هـدف الدراسة.

- - إجـراء معـاملات الصـدق والثبـات علـى الاختبـارات البدنيـة و المهاريـة المستخدمة قيد البحث.

- - التعرف على انسب زوايا الكاميرات والتوقيت المناسب للتصوير -

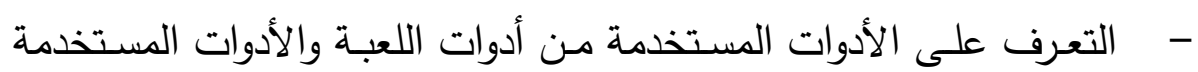

$$
\text { في البرنامج التدريبي. }
$$

- - التأكد من صلاحية البيئة الرملية وملائمتها لتحقيق الغرض من البحث. المعاملات العلمية للاختبارات المهارية قيد البحث :

\section{Validity الصدق}

تم حساب الصدق عن طريق صدق التمايز لمجموعتين احدهما مميزة وعددها ( • () لاعبين والاخري اقل تميزا وعددها ( • () لاعبين حيث تم تطبيق

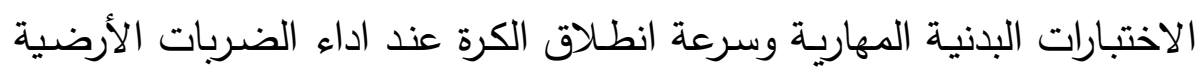

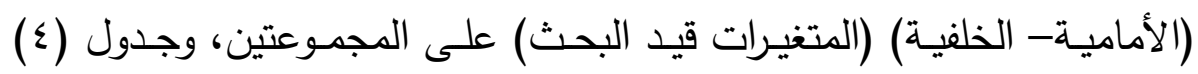
يوضتح دلالة الفروق بين المجموعتين :

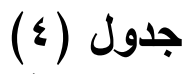

دلالة الفروق بين المجموعتين المميزة والغير مميزة في الاختبارات

\begin{tabular}{|c|c|c|c|c|c|c|}
\hline \multirow[t]{2}{*}{ ت } & \multicolumn{2}{|c|}{ المجمو عةزة غير } & \multicolumn{2}{|c|}{ المبموزة عة 1 المجيزة } & \multirow[t]{2}{*}{ الافتبار / وحدة القياسر } & \multirow[t]{2}{*}{ م } \\
\hline & $\varepsilon$ & s & $\varepsilon$ & م & & \\
\hline$* 0, r_{0}$ & T.17 & ro, & $16 . \varepsilon$ & $r 9 . r$ & الوثب العمودي لسارجنت (سم) & 1 \\
\hline$* r, \cdot r$ & 1619 & r.99 & .619 & 1611 & (ץ) حجلات يمين (م/ث) & $r$ \\
\hline
\end{tabular}

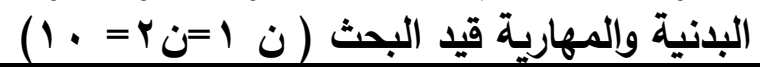


VVY

\begin{tabular}{|c|c|c|c|c|c|c|}
\hline$* r, T V$ & $1 \Lambda_{6} \mid$ & $r_{6} \cdot 1$ & .679 & 1610 & (r) حجلات يسار (م/ث) & r \\
\hline$* r, \wedge r$ & 16.0 & 0,1 & .699 & r، rᄉ & سمين (ثرعة تحـرك القـدمين بـالجري & $\varepsilon$ \\
\hline$*$ *,q1 & 1611 & 0,0 & .697 & $r_{601}$ & سيسار (ث) تحــرك القــدمين بـالجري & 0 \\
\hline$* r, q q$ & 1611 & $0,$. & $.6 \wedge 0$ & $r_{600}$ & سيـين (ث) & 7 \\
\hline$* r, \ldots$ & 1677 & $76 \cdot 1$ & 1611 & $\varepsilon 6 \cdot 1$ & سيـار (ثرعة تحـرك القــدمين بزحلقــة & V \\
\hline$* r, \wedge 1$ & 1.04 & $V_{6} 11$ & $16 Y \leqslant$ & $\varepsilon .07$ & 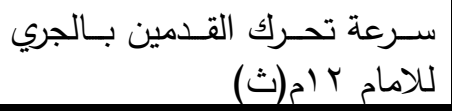 & $\wedge$ \\
\hline
\end{tabular}

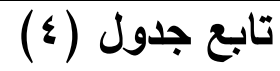

دلالة الفروق بين المجموعتين المميزة والغير مميزة في الاختبارات

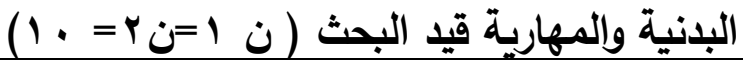

\begin{tabular}{|c|c|c|c|c|c|c|}
\hline \multirow[t]{2}{*}{$\ddot{ت}$} & \multicolumn{2}{|c|}{ المجمو عة غبهر } & \multicolumn{2}{|c|}{ 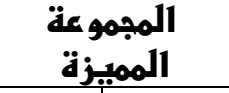 } & \multirow{2}{*}{ الاهنتبار / وهدة القباسر } & \multirow{2}{*}{ م } \\
\hline & $\varepsilon$ & 5 & $\varepsilon$ & م & & \\
\hline$* \varepsilon, V$ & $167 \mathrm{~V}$ & A,rT & $16 \cdot 1$ & 0.11 & عدو r r م في خط مستقيم(ث) & 9 \\
\hline$* \Gamma, \tau \wedge$ & $r_{6} \cdot \varepsilon$ & ס ס & $16 \cdot r$ & $1 \pi, 00$ & العنكبوتي (ث) & 1 . \\
\hline$* \Gamma, \varepsilon \Gamma$ & $r_{6} \cdot V$ & r & $16 \cdot r$ & $r q_{6} \leqslant V$ & التتابع (ث) & 11 \\
\hline$*$ r, & r.0 T & $1 V_{6} \cdot 9$ & $1, \cdot 7$ & $1 \mu_{6} 0 \mathrm{~V}$ & الجري الزجزاجي (ث) & ir \\
\hline$* \varepsilon_{6} \wedge 1$ & $r_{6} 9 \varepsilon$ & r) & 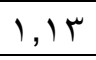 & ru & داير للضربات الأرضية الأمامية & 1r \\
\hline * ฯ, ג & 1,19 & tr & $\cdot, \vee \wedge$ & ro & داير للضربات الأرضية الخلفية & $1 \leq$ \\
\hline$* 0, \wedge$ & $r_{6} \cdot 7$ & $1 T_{67}$ & 1,00 & Y. r $^{\prime}$ & سأمـرعة انطـلاق الكـرة (الضـربة & 10 \\
\hline$* 7, \ldots$ & $r_{6} 94$ & $1 \varepsilon_{6}$ & $1, r$ & $Y \cdot 6 \leqslant T$ & سلخـرعة انطـلاق الكـرة ( الضـربة & 17 \\
\hline
\end{tabular}

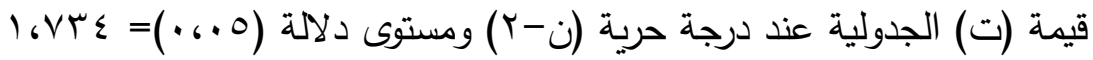
يتضـح مـن جدول (ع) وجـود فروق دالة إحصـائيا عند مسـتوى دلالـة (0 •، • ) بين المجموعتين المميزة والغير مميزة لصـالح المجموعة المميزة في

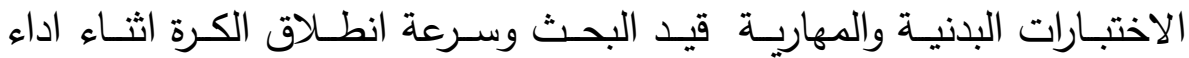

\section{مجالة أسيوط لعلوم وفنـون التربية الرياضية}


الضربات الأرضية (الأمامية- الخلفية) مـا يعطي دلالة مباشرة على صدق الاختبارات.

\section{Reliability الثبات}

تم حساب ثبات الاختبارات عن طريق تطبيق الاختبار وإعادة تطبيقه بعد (0 1) يوم، وتم حساب معامل الارتباط بين درجات التطبيقين الأول والثاني على عدد ( • () من مجتمع البحث وخارج العينة الأصلية.

\section{جدول (•)}

دلالة الفروق بين المجموعتين المميزة والغير مميزة في الاختبارات المهارية

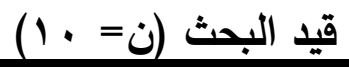

\begin{tabular}{|c|c|c|c|c|c|c|}
\hline \multirow{2}{*}{ J } & \multicolumn{2}{|c|}{ 1انتطبـز } & \multicolumn{2}{|c|}{ التطبئز الأول } & \multirow{2}{*}{ الافنتبار / وحدة القباسر } & \multirow{2}{*}{ م } \\
\hline & $\varepsilon$ & 5 & $\varepsilon$ & r & & \\
\hline$* .691$ & r.71 & ro, V & $r_{6} 17$ & ro, & الوثب العمودي لسارجنت ( سم ) & 1 \\
\hline$* \cdot . \wedge \varepsilon$ & $r_{6} \leqslant 1$ & $.6 \mathrm{VI}$ & 1619 & $.67 Y$ & (ب) حجلات يمين (م/ث) & r \\
\hline$*,, \vee\urcorner$ & $r_{600}$ & 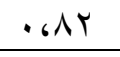 & 1611 & . ،八 & (ب) حجلات يسار (م/ث) & r \\
\hline$* .619$ & 1, 0 & $\varepsilon 69$ & 16.0 & 0,1 & سرعة تحرك القدمين بالجري يمين & $\varepsilon$ \\
\hline * . ،八9 & l, & $0, V$ & 1.91 & 0,0 & ســـرعة تـــرك القـدمين بــالجري & 0 \\
\hline$* .991$ & $r_{6} V V$ & $06 \cdot 1$ & $\left|M_{6}\right|$ & 06. & سمين سـرعة تحــرك القــدمين بزحلقـــة & 7 \\
\hline$*$ * ، ^ᄉ & r.70 & $76 \cdot \varepsilon$ & 1677 & $76 \cdot 1$ & سيـــرعة تـــرك القــدمين بزحلقـــة & V \\
\hline$* .69 r$ & 1.74 & $\left.v_{6}\right) \mathrm{r}$ & 1.04 & $\left.V_{6}\right) 1$ & سلامـام برعة تحــرك القــدمين بـالجري & $\wedge$ \\
\hline$* .6 \vee \leq$ & 16.0 & A, rt & $167 \mathrm{~V}$ & A,rT & عدو r r م في خط مستقيم(ث) & 9 \\
\hline$* .6 \vee 9$ & r.VT & $176 \cdot V$ & $\left.r_{6}\right) \varepsilon$ & 176.0 & العنكبوتي (ث) & 1. \\
\hline * • ،八 & r.99 & $r_{6} .0$ & $r_{6} \cdot V$ & r $\left.T_{6}\right)$ & التتابع (ث) & 11 \\
\hline$* .691$ & $r_{6} \wedge 9$ & $1 V_{6} \cdot r$ & r.or & $1 V_{6} \cdot 9$ & الجري الزجزاجى (ث) & ir \\
\hline$*$. . A V & $r_{6} \varepsilon 9$ & 11 & r.9 & r) & داير للضـربات الأرضية الأمامية & r \\
\hline
\end{tabular}




\begin{tabular}{|c|c|c|c|c|c|c|}
\hline & & & & & (عدد) & \\
\hline$* \cdot(\wedge)$ & 1 6 11 & YI & 1.99 & rY & (عدد) دايـر للضـربات الأرضـية الخلفيـة & $1 \varepsilon$ \\
\hline$* .997$ & $1.9 \mathrm{~V}$ & $1 \mu_{6} \cdot 1$ & $r_{6} .7$ & IT, & سألمامية انطـلاق الكـرة ( الضــربة & 10 \\
\hline$* . ، \wedge 9$ & $r_{6} \cdot 1$ & $1 \varepsilon_{6} \cdot r$ & $r_{6} 9 r$ & $1 \varepsilon_{6}$ & سلخـرعة انطـلاق الكـرة ( الضــربة & 17 \\
\hline
\end{tabular}

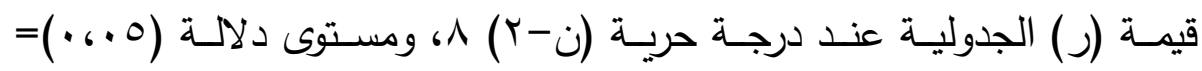
$(\cdot .0 \leq 9)$

يتضـح مـن جـدول (0) أن معـاملات الارتبـاط بـين تطبيـق الاختبـار

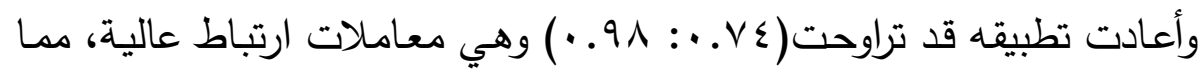
يشير الى ثبات الاختبارات البدنية والمهاريـة قيد البحث وسرعة انطلاق الكرة

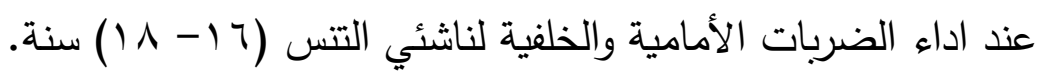
خطوات تطبيق البحث :

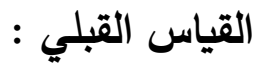

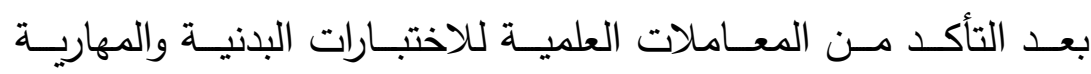
المسـخدمة وسـرعة انطـلاق الكـرة اثتـاء اداء الضـربات الأرضـية (الأماميـة-

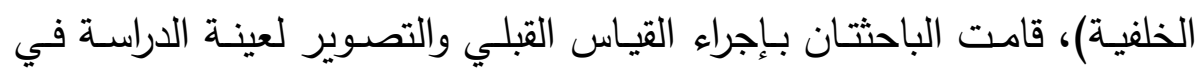

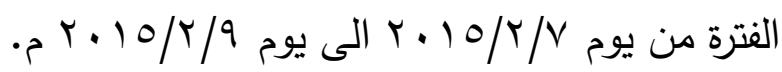
خطوات تصميم البرنامج التدربيج : الهدف العام للبرنامـج: يهـدف البرنـامج التـدريبي المقتـرح الـى تحسـين أداء حركـات القـدمين

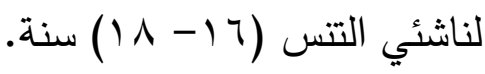

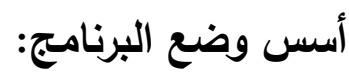


تم تطبيق البرنامج التدريبي المقترح في نهاية فترة الإعداد البدني العام

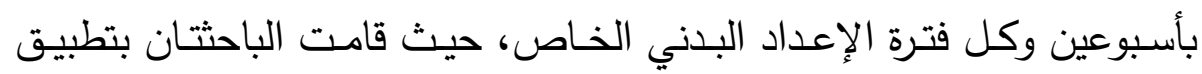
الأسس العامة للتدريب الرياضي من حيث الإحماء والتهدئة والأدوات المطلوبة

ولضمان نجاح تخطيط البرنامج راعت الباحثتان الأسس التالية : - - ملائمة البرنامج للمرحلة السنية قيد البحث وخضوعه للهدف العام للبحث.

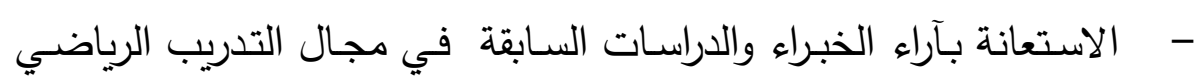
بصفة عامة والتس بصفة خاصة. - - تحديــ وإتبـاع أهـم واجبـات التدريب الرياضـي للناشئين ومحاولـة تـوفير الأدوات المستخدمة المعينة على تحقيق البرنامج للغرض من تطبيقه.

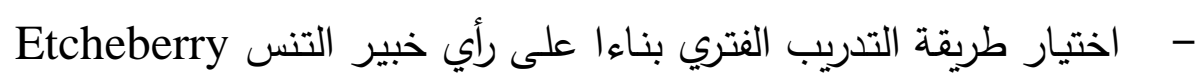
أن التنس رياضة تتأسس على التدريب الفتري، وهذا يتفق مع أراء الخبراء

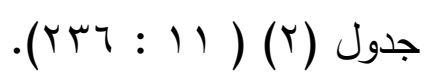

- مراعـاة أن تتشـابه التمرينـات المسـتخدمة في البرنـامج مـع طبيعـة اداء حركات القدمين لناشئي التس مرفق رقم ( r ).

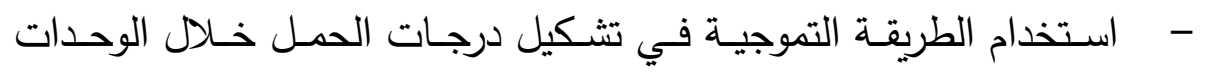
التدريبية، مراعاة الالتزام بمبادئ تتمية الصفات البدنية من حيث الارتفاع

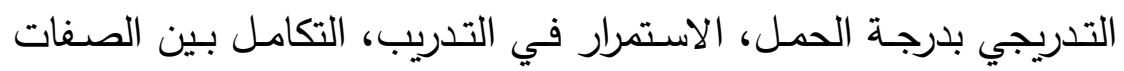

$$
\begin{aligned}
& \text { البدنية (9 " : .0 10 - . } 7 \text { (1). } \\
& \text { اجزاء الوحدة التدريبية : }
\end{aligned}
$$

الإحماء : يعادل • 1 - •r\% من زمن الوحدة التدريبية.

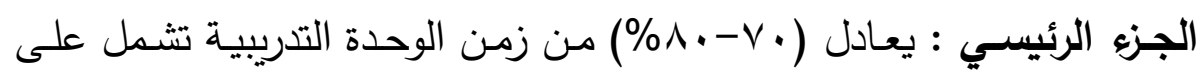
التمرينات التي تحسن من حركات القدمين لناشئ التس والتي تتشـابه من حيث تركيب وشكل الأداء واتجاه العمل العضلي مـع تلك الحركات التي تؤدي في

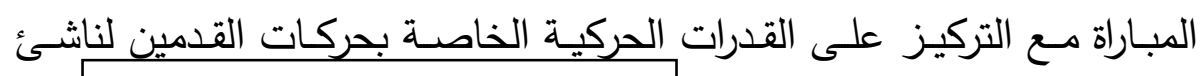
مجلة أسيوط لعلوم وفنون التربية الرياضية 
التنس ( قدرة عضـلية - سـرعة انتقاليـة وحركيـة - رشـاقة ) خـلال وحدات البرنامج التدريبي.

الجزء الختـامي : تعادل (V- - (\%) من زمن الوحدة وتحتوى على تمرينات استرخاء وتهيئة، عرض نموذج لوحدة تدرببية مرفق رقم (0). نماذج لتمرينات المستخدمة في البرنامج :

من خلال الاطلاع على المراجع والأبحاث العلمية المرتبطة تم اختيار

$$
\begin{aligned}
& \text { التمرينات المستخدمة بالبرنامج المقترح مرفق رقم (r). } \\
& \text { مخطط للبرنامج التدريبي المقترح : }
\end{aligned}
$$

بناءا على نتائج جدول (1) والاطـلاع على المراجع العلمية المرتبطة بموضوع البحث تم وضع مخطط للبرنامج التدريبي المقترح ليحقق الهدف الذي

$$
\text { وضع من اجله مرفق رقم (7). }
$$

تنفيذ البرنامج :

بعد الانتهاء من القياسـات القبلية تم تطبيق البرنـامج التدريبي المقترح

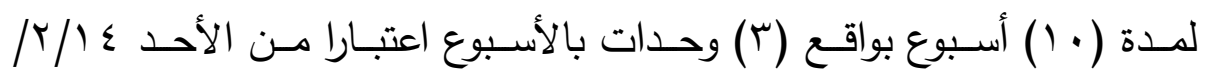

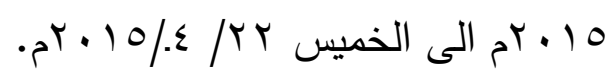

$$
\begin{aligned}
& \text { القياس البعدي : }
\end{aligned}
$$

بعد الانتهاء من تطبيق البرنامج التدريبي تم إجراء القياس البعدي لعينة

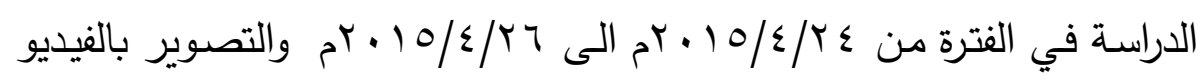
وقد تمت جميع القياسات على نحو ما تم إجراؤه في القياس القبلي. المعاملات الإحصائية : المعاية اســـخدمت الباحثثــان المعالجــات الإحصـــائية التاليــة باســتخدام

$$
\text { برنامجٍ Spss بنسبة دلالة (0 • ، ) : }
$$


- المتوسط الحسابي.

- الانحراف المعياري.

- اختبار (ت) لمجموعة واحدة، ولمجموعتين.

- النسبة المئوية.

- نسبة التحسن\% (نسبة التغير).

- معامل الارتباط لبيرسون (0). 


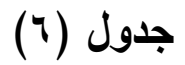

عرض النتائج:

دلالة الفروق بين القياس القبلي والبعدي لاختبارات القدرة العضلية لناشئي

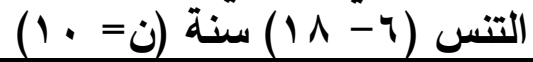

\begin{tabular}{|c|c|c|c|c|c|}
\hline ت & مجـف & مجذف & القياسرة وحدة & 1فتبارات القدرة & م \\
\hline$* \Lambda_{6} \vee \wedge$ & $\leqslant 9 \leqslant 60$ & 77,00 & سم & الوثب العمودي لسارجنت & 1 \\
\hline$* q_{6} \mathrm{Vr}$ & $\Lambda_{6}+1$ & 1,00 & م/ث & (r) حجلات يمين & $r$ \\
\hline$* \Lambda_{6} Y$ & $V_{6} 0$ & $\left.\Lambda_{6}\right) \mathrm{T}$ & م/ث & (ץ) حجلات يسار & $r$ \\
\hline
\end{tabular}

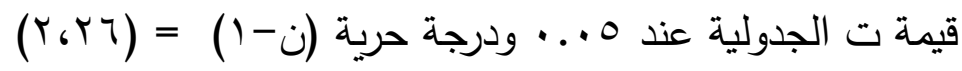

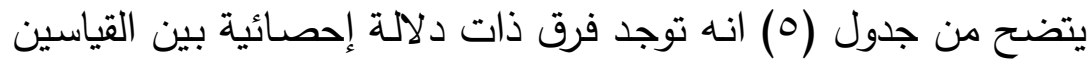

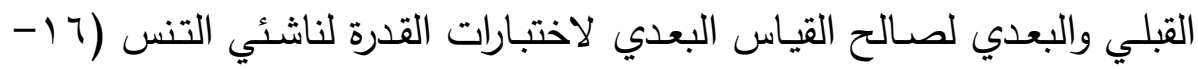

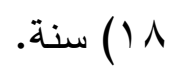

\section{جدول (v)}

دلالة الفروق بين القياس القبلي والبعدي لاختبارات السرعة لناشئي التنس

$$
\text { (1. }
$$

\begin{tabular}{|c|c|c|c|c|c|}
\hline ت & مجـ ف & مجـف & القباسدة وسر & افنتبارات الستر عة & م \\
\hline$* V_{6} 71$ & $r r_{6} 70$ & $1 \leq 6$ & ث & سرعة تحرك القدمين بالجري يمين & 1 \\
\hline$* V_{6} 97$ & r & 10.14 & ث & سرعة تحرك القدمين بالجري يسار & r \\
\hline 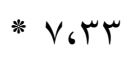 & ro, & $1 \varepsilon_{6} \Lambda$ & ث & سرعة تحرك القدمين بزحلقة يمين & r \\
\hline$* V_{6} 0$ & r7, 11 & $106 \cdot 1$ & ث & سرعة تحرك القدمين بزحلقة يسار & $\varepsilon$ \\
\hline$* V_{6} 7$ & $\Lambda_{6} 0 \mathrm{Y}$ & 1.09 & ث & سرعة تحرك القدمين بالجري للامام Y'م & 0 \\
\hline$* V_{6} 9$ & $V_{6} T^{2}$ & $V_{697}$ & ث & عدو r T م في خط مستقيم & 7 \\
\hline
\end{tabular}

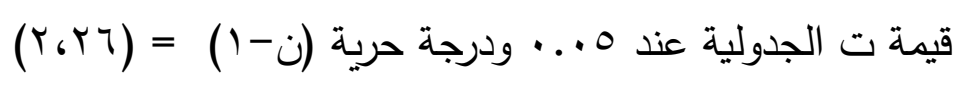

يتضح من جدول(V) انه توجد فرق ذات دلالة إحصائية بين القياسين

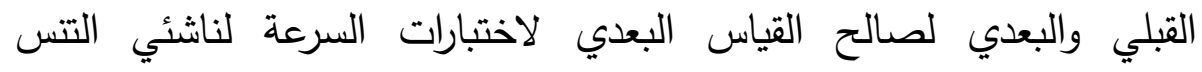

$$
\text { (11 - (17) }
$$


جدول (^)

دلالة الفروق بين القياس القبلي والبعدي لاختبارات الرثاقة لناشئي التنس (1) التس (1)

\begin{tabular}{|c|c|c|c|c|c|}
\hline \multicolumn{6}{|c|}{ 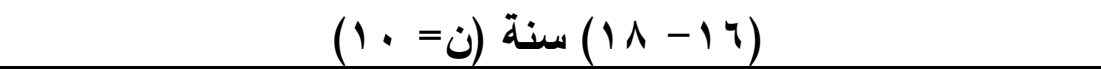 } \\
\hline ت & مجـف & مجذف & وحدة القياس & 1غتبارات الرشاقة & مـ \\
\hline$* \varepsilon, V_{0}$ & $91 ، \wedge \varepsilon$ & $r 0.74$ & ث & العنكبوتى & 1 \\
\hline$* \varepsilon_{6} \wedge \mu$ & 194 & $r V_{6}, T_{1}$ & ث & التتابع & r \\
\hline$* \varepsilon_{0} 0$ & $9 \cdot 61$ & ro,.l & ث & الجري الزجزاجي & $r$ \\
\hline
\end{tabular}

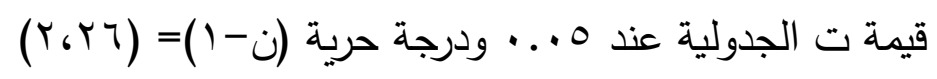

يتضح من جدول(^) انه توجد فرق ذات دلالة إحصائية بين القياسين

القبلي والبعدي لصالح القياس البعدي لاختبارات الرشاقة لناشئي التتس

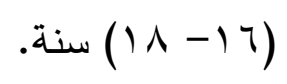

\section{جدول (9)}

دلالة الفروق بين القياس القبلي والبعدي للاختبارات المهارية

\begin{tabular}{|c|c|c|c|c|c|}
\hline ت & مجد ف & مجذف & القياسرة & 1لإتبارات المهارية & م \\
\hline$=4, \mathrm{VT}$ & YYT & $\varepsilon$ & عدد & داير للضربات الأرضية الأمامية & 1 \\
\hline$* 4.61$ & $r \leq r$ & «0 & عدد & داير للضربات الأرضية الخلفية & $r$ \\
\hline
\end{tabular}

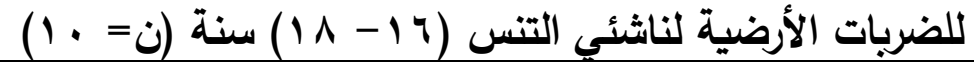

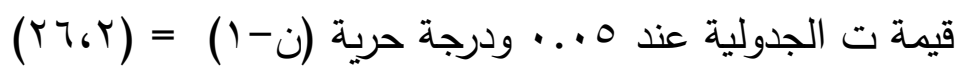

يتضح من جدول (9) انه توجد فرق ذات دلالة إحصائية بين القياسين

القبلي والبعدي لصالح القياس البعدي للاختبارات والمهارية للضربات الأرضية

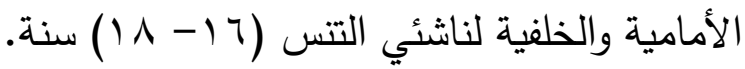




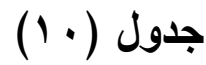

دلالة الفروق بين القياس القبلي والبعدي لسرعة انطلاق الكرة عذد اداء الضربات

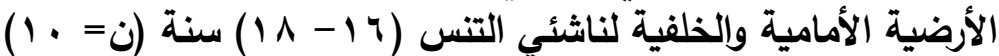

\begin{tabular}{|c|c|c|c|c|c|}
\hline ت & مجـ ف & مجـذ & القياسدة & 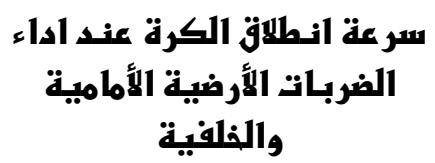 & م \\
\hline$* \varepsilon_{6} \varepsilon$ & $11.6 V$ & ro, & م/ث & سرعة انطلاق الكرة (الضربة الأمامية ) & 10 \\
\hline$* 0,1 \mathrm{r}$ & 198614 & $\mu_{\Lambda}, \mu^{2}$ & م/ث & سرعة انطلاق الكرة ( الضربة الخلفية ) & 17 \\
\hline
\end{tabular}

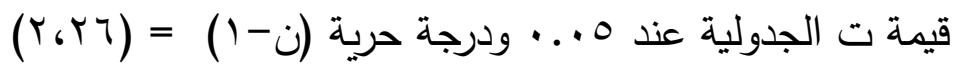

يتضح من جدول (· () انه توجد فرق ذات دلالة إحصائية بين

القياسين القبلي والبعدي لصالح القياس البعدي سرعة انطلاق الكرة عند اداء

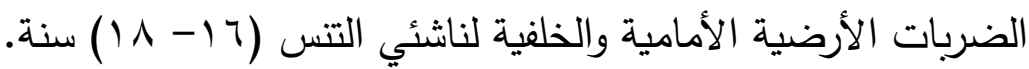

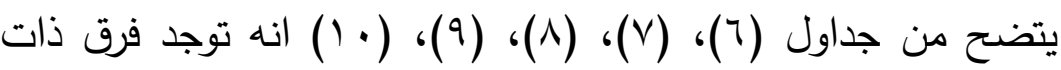
دلالة إحصائية بين القياسين القبلي والبعدي لصالح القياس البعدي للاختبارات البدنية والمهارية قيد البحث وسرعة انطلاق الكرة عند اداء الضربات الأمامية والخلفية لناشئي التنس (T (1 1 1) سنة مما يدل على التأثير الايجابي للبرنامج التدريبي المقترح وبذلك يكون قد تحقق فرض البحث.

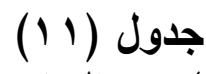

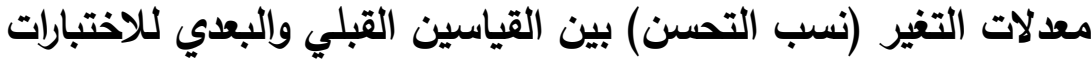

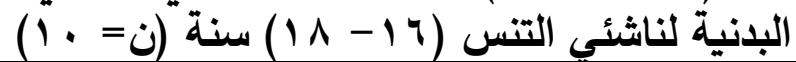

\begin{tabular}{|c|c|c|c|c|c|}
\hline نسبة التحسز & البعدياسي & القبالي & القياسرة & الاختبارات البدنية & م \\
\hline$r 1,0$. & $\left.\sum V_{6}\right)$ & $r \Lambda_{6} .9$ & سم (- (- مـ & الوثب العمودي لسارجنت & 1 \\
\hline rA, ro & r.or & $1, \wedge r$ & م/ث & (r) حجلات يمين & r \\
\hline Tr.OT & r.ra & 1.69 & 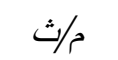 & (r) حجلات يسار & r \\
\hline$\varepsilon r, 1$ & $r_{6} .1$ & r.or & ث & سرعة تحرك القدمين بالجري يمين & $\varepsilon$ \\
\hline
\end{tabular}




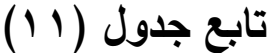

معدلات التغير (نسب التحسن) بين القياسين القبلي والبعدي للاختبارات

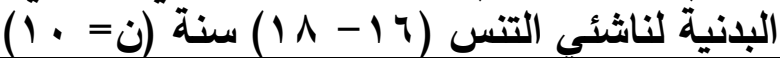

\begin{tabular}{|c|c|c|c|c|c|}
\hline نسبة التحسن & البعدياس & القباسي & القياسر ودة & الاذتبارات البدنية & \\
\hline$\varepsilon r_{6} \varepsilon V$ & 1.99 & r.or & ث & سرعة تحرك القدمين بالجري يسار & 0 \\
\hline$\varepsilon 1, \vee \wedge$ & r..9 & r.09 & ث & سرعة تحرك القدمين بزحلقة يمين & 7 \\
\hline$r \Lambda, V T$ & $r, r$ & r.09 & ث & سرعة تحرك القدمين بزحلقة يسار & $v$ \\
\hline$r \leqslant 610$ & r.11 & \&61 & ث & سرعة تحرك القدمين بالجري للامام r ام & $\wedge$ \\
\hline$V_{6} V_{6} \varepsilon r$ & $\varepsilon_{G}, Y$ & 0.11 & ث & عدو r r م في خط مستقيم & 9 \\
\hline$r M, r Y$ & 1.659 & 115.00 & ث & العنكبوتى & 1. \\
\hline$r \cdot 6 V_{0}$ & $r \leqslant 607$ & $r .699$ & ث & 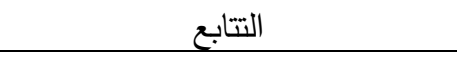 & 11 \\
\hline$r r, \cdot \Lambda$ & 1.609 & 17.09 & ث & الجري الزجزاجي الجي & ir \\
\hline
\end{tabular}

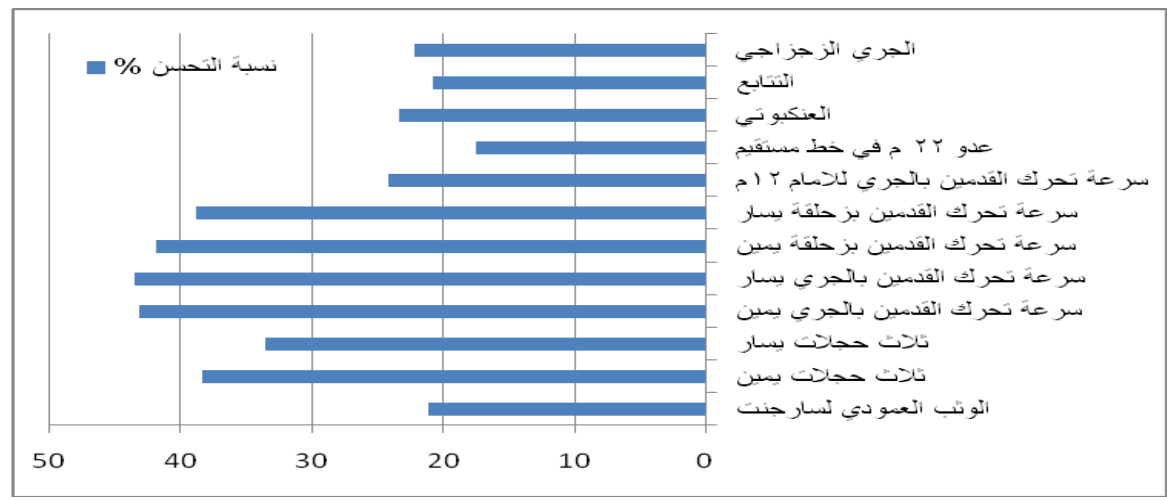

شكل (1)

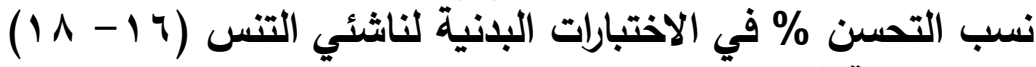
سنة في القيّاس البعدي عن القياس القبلي لناتي

يتضح من جدول (1)'، وشكل (1) انه توجد فروق في معدلات التغير (نسبة التحسن) بين القياسين القبلي والبعدي لصالح القياس البعدي مجلة أسيوطلعلوم وفنون التربية الرياضية 


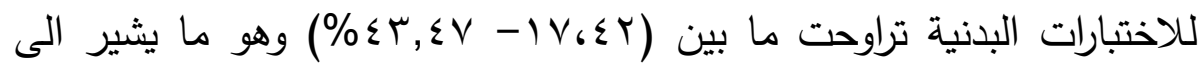
تأثير البرنامج الإيجابي.

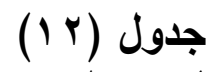

معدلات التغير (نسب التحسن) بين القياسين القبلي والبعدي للاختبارات

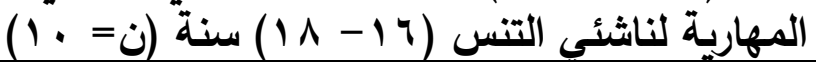

\begin{tabular}{|c|c|c|c|c|c|}
\hline نسبة التحسسن ٪\% & البعياسر & القباسلي & القياسدة وحدة & 1الفتبارات المهارية & م \\
\hline IT,VT & rq & Yo,0 & عدد & داير للضربات الأرضية & 1 \\
\hline $10, \mathrm{HA}$ & r. & $r q$ & عدد & داير للضربات الأرضية الخلفية & $r$ \\
\hline
\end{tabular}

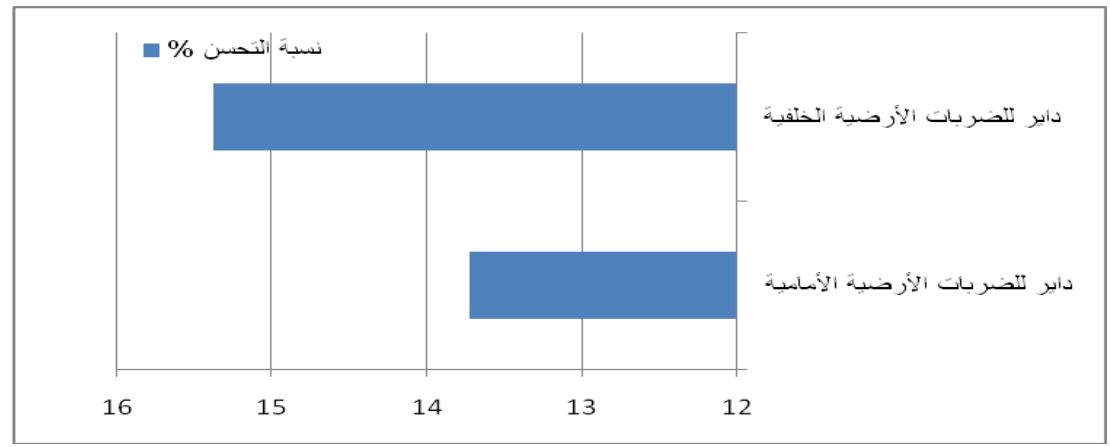

\section{شكل (r)}

نسب التحسن \% في الاختبارات المهارية لناشئي التنس في القياس البعدي عن القياس القبلي

يتضح من جدول(Y ( )، وشكل (Y) انه توجد فروق في معدلات التغير

(نسبة التحسن) بين القياسين القبلي والبعدي لصالح القياس البعدي للاختبارات

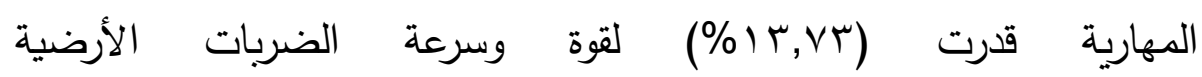

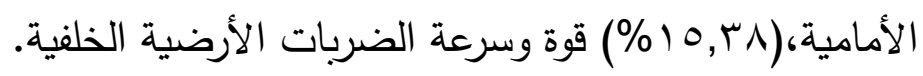




$$
\text { جدول (1T) }
$$

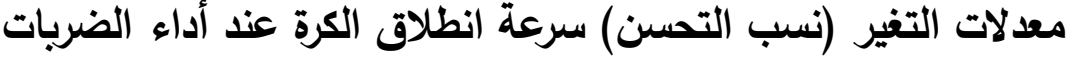

\begin{tabular}{|c|c|c|c|c|c|}
\hline 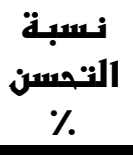 & البهـباسي & القبـباسي & القياسدة & 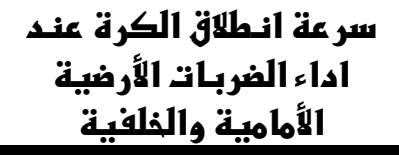 & \\
\hline$\left|V_{G}{ }^{\prime}\right|$ & $r r_{6} V$ & $r . G T r$ & م/ث & $\begin{array}{c}\text { سرعة انطلاق الكرة (الضربة } \\
\text { الأمامية }\end{array}$ & 1 \\
\hline $\mid V_{6} \leq 1$ & $r \varepsilon_{6}, 1$ & $r_{0}, 6 \leqslant 0$ & م/ث & سرعة انطلاق الكرة (الضربة & r \\
\hline
\end{tabular}

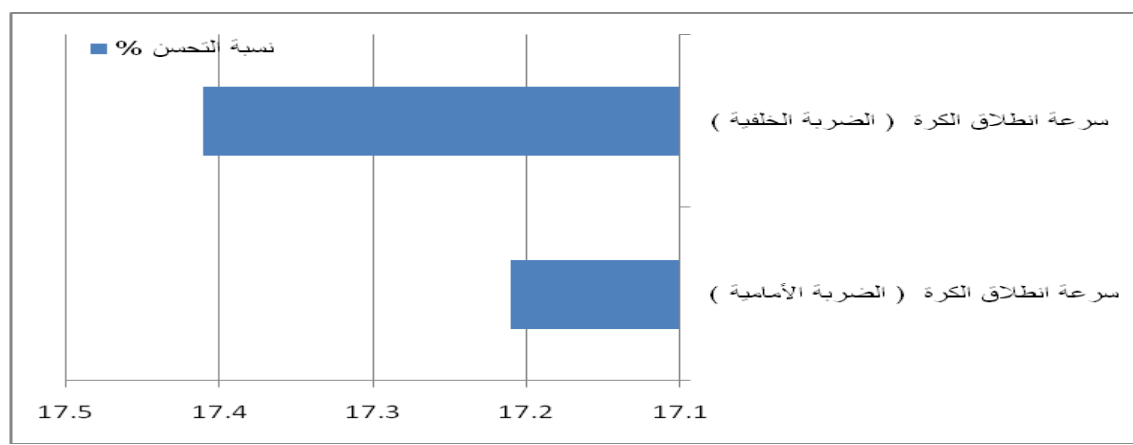

شكل (r)

نسب التحسن \% في وسرعة الانطلاق للكرة اثناء اداء الضربات الأرضية (الأمامية- الخلفية) لناشئي التس ( 1 ( - 1 1 ) سنة في القياس البعدي عن القياس القبلي

يتضح من جدول (T I) وشكل (T) انه توجد فروق في معدلات التغير (نسبة التحسن) بين القياسين القبلي والبعدي لصالح القياس البعدي في سرعة

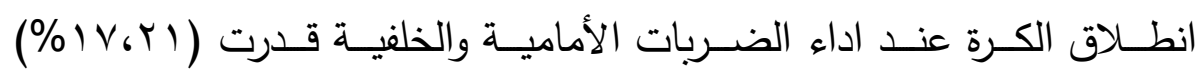

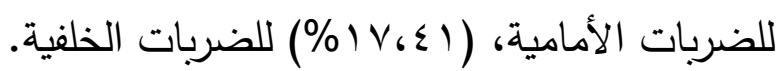

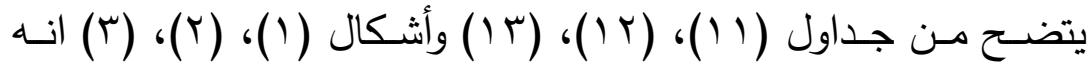
توجد فروق في معدلات التغير (نسبة التحسن) بين القياسين القبلي والبعدي 
لصالح القياس البعدي للاختبارات البدنية والمهارية قيد البحث وسرعة انطلاق

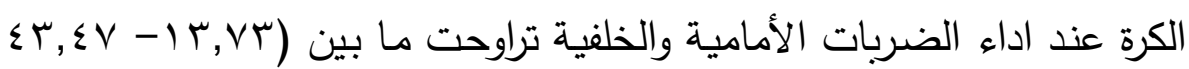
\%) مما يشير لتأثير البرنامج الايجابي ويحقق فرض البحث. مناقشة النتائج : مانسيز

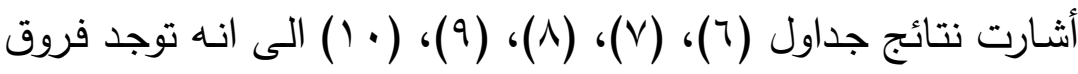

دالة إحصائيا بين القياسين القبلي والبعدي لصالح القياس البعدي في متغيرات البحث لناشئي التنس (7 ( - 1 1) سنة وتعزو الباحثتان هذه الفروق المعنوية لعينة البحث في القياس البعدي عنها في القياس القبلي، وكذلك لعرض جداول

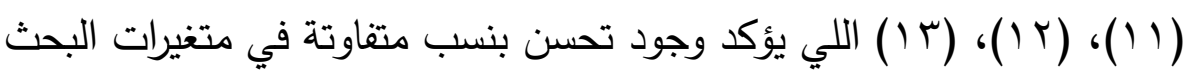
مرجع ذللك الى ما يلي: أولاً: اختيار نوع التدريب على الرمال وما له من اثر واضح في تحسين مستوى عناصر اللياقة البدنية الخاصـة بحركات القدمين لناشئي التنس ويفسر تحسن فعالية حركات القدمين حيث سجلت اكبر نسب تحسن في اختبارات السرعة

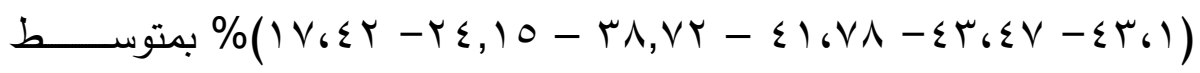

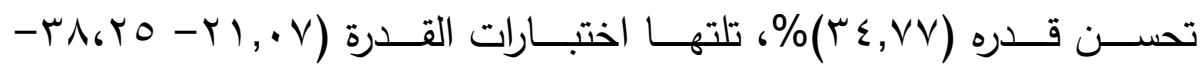

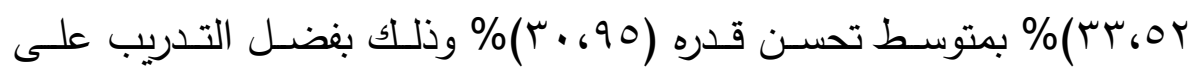

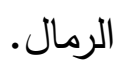

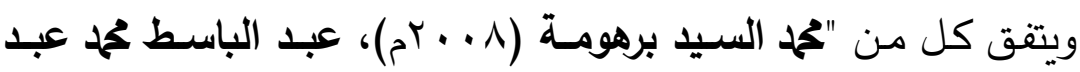

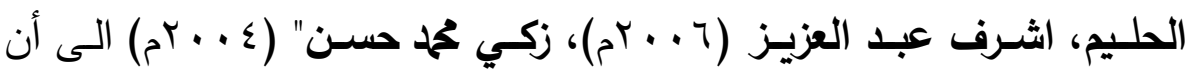
التدريب على الرمـال تسهم في زيـادة القدرات العضلية للطرف السفلي الذي يتأثر أكثر نتيجة المقاومة المباشرة للرمال عن اي وسط أخر يتم فيه التدريب فمقاومـة الرمال تهتم أكثر بعضـلات الرجلين فيعد من أهم انواع التدريب التي تعمل على زيـادة قدرة عضـلات الرجلين من خـلال المقاومـة التي تحدث اثثاء الحركة على الرمال مما يسهح بشكل فعال في وصول المتدرب الى حالة بدنية

\section{مجلة أسيوط لعلوم وفنون التربية الرياضية}


عالية تسهم في زيـادة قدرتهـ على اداء الواجبات المهاريـة ولذا فكان اختيار الباحثتان لمثل هذا النوع من التدريب التأثير الأكبر على مهارة حركات التهات القدمين

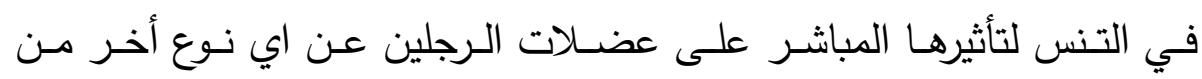

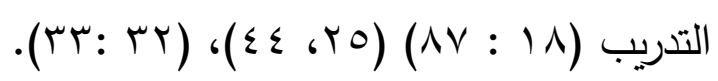

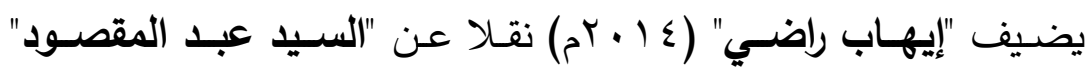

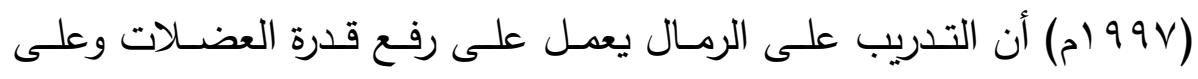

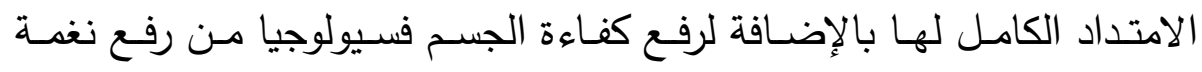

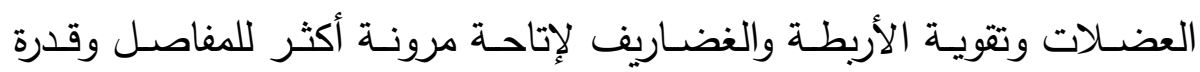

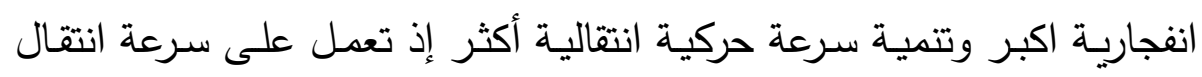
التأثيرات العصبية مما يفسر تطور عنصر السرعة اثناء التدريب على الرمال

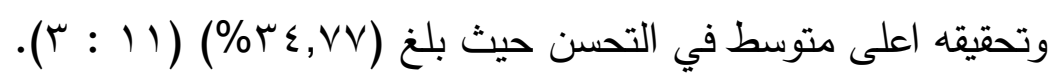
ثانياً: التخطيط الجيد عند تصميم البرنامج التدريبي المقترح من ناحية التركيز

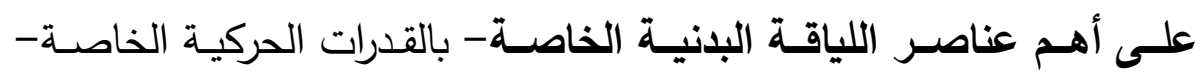

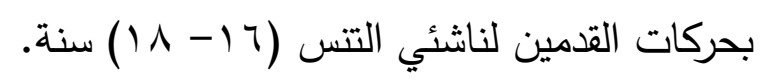

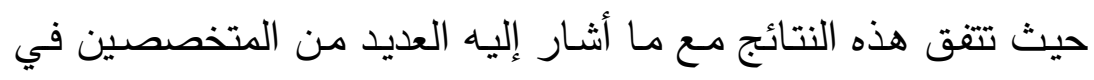

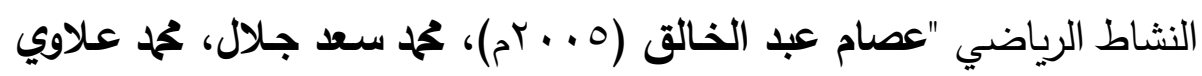

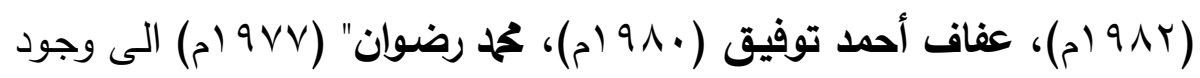

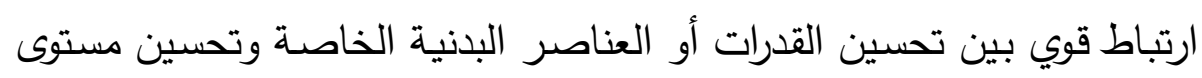

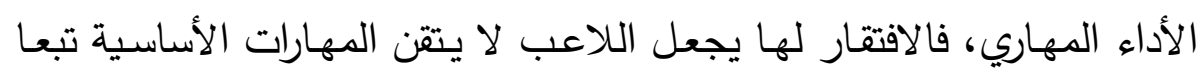

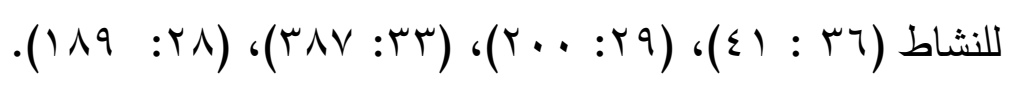

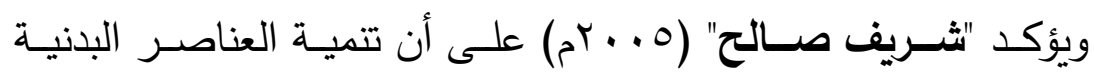

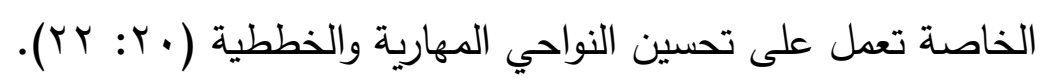

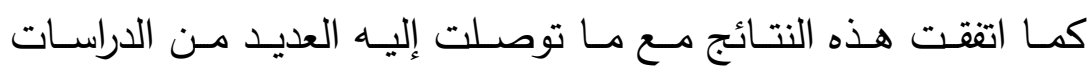

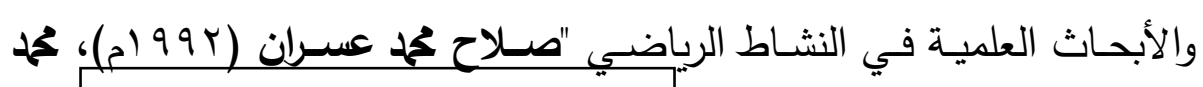

\section{مجلة أسيوط لعلوم وفنون التربية الرياضية}




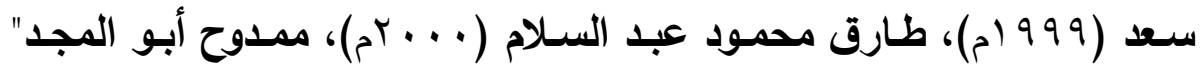

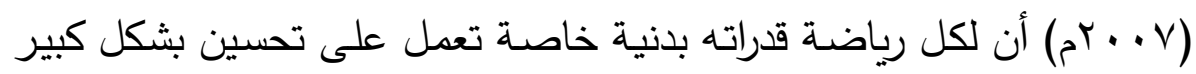

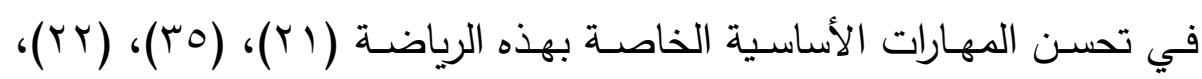

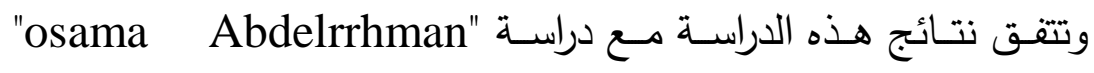

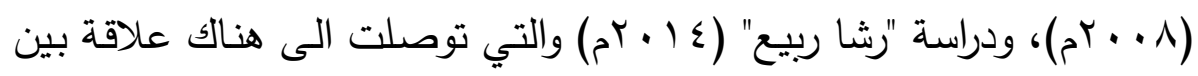

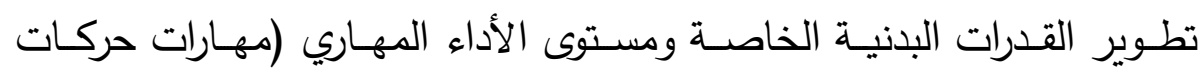

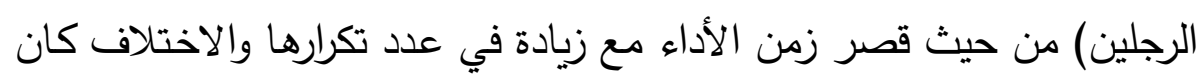

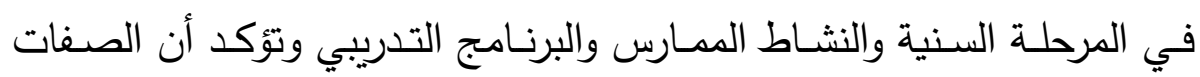

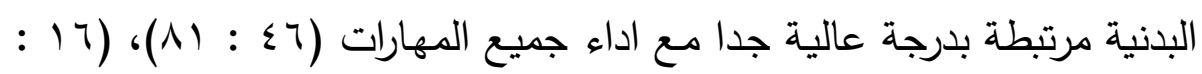
. (91 ، 94

كمـا أن هذه النتائج تتفق مـع مـا أشـار إليـه "عـادل عبــ البصـير" (999 (1) نقلا عن "مونتزفاي Muttenzfay" أن تتمية القدرة العضلية (القوة

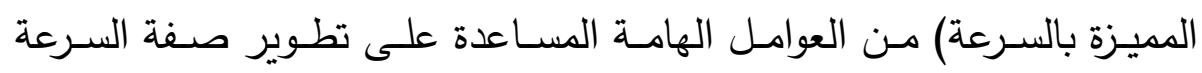

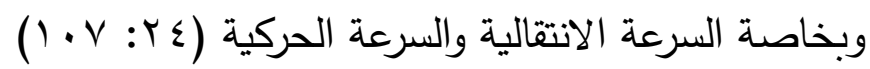

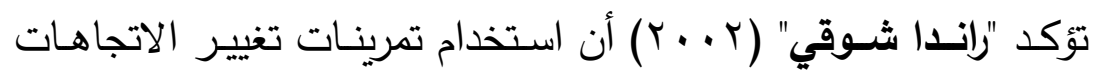

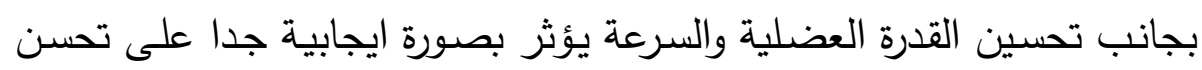
الرشاقة وتضيف أن التدريب المستمر للقدرة العضلية (فوق الثلاث أسـابيع)

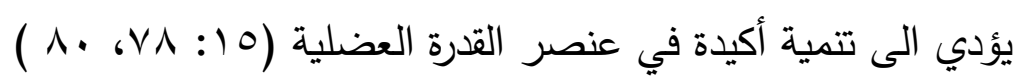

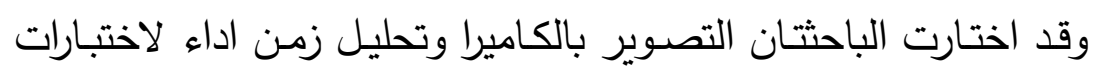

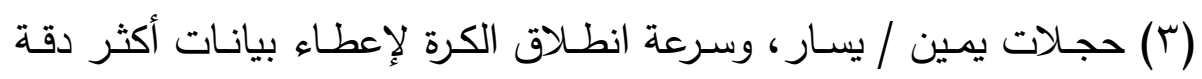

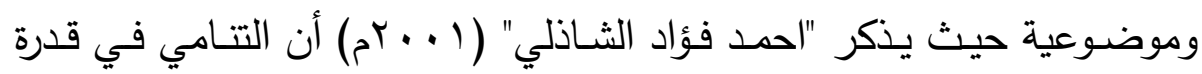

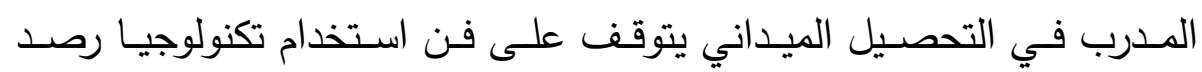

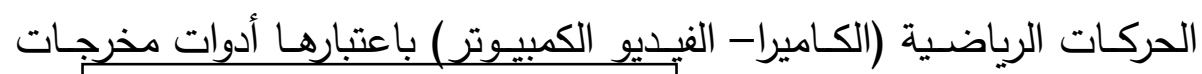

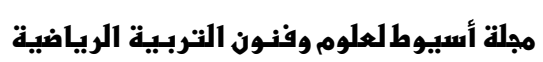


ايجابيـة للحصـول على بيانـات دقيقة وموضـوعية معبرة عن الأداء الحركي

(10: 10$)$

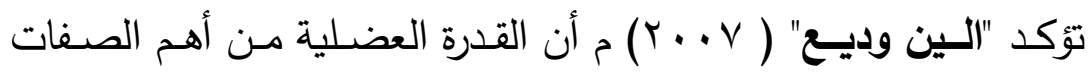

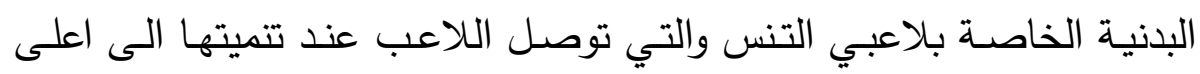

المستويات في التس فهي مزيج من مركب السرعة والقوة (9 : 1 (1).

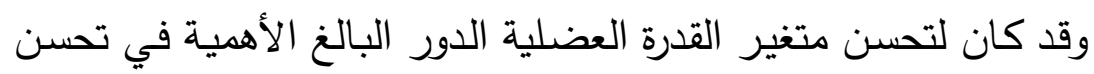

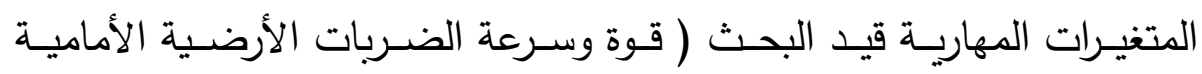

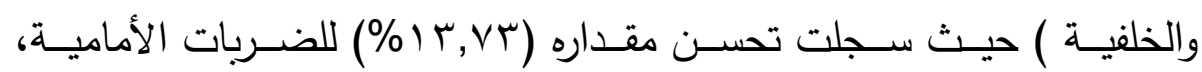

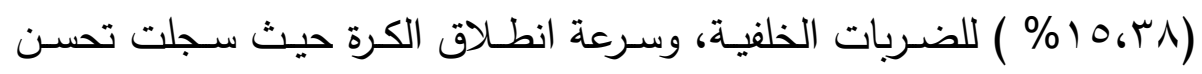

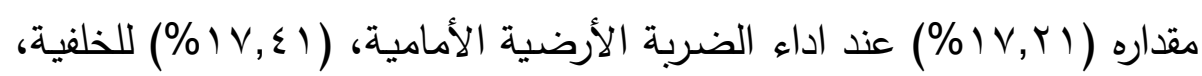

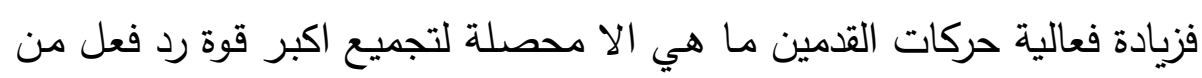

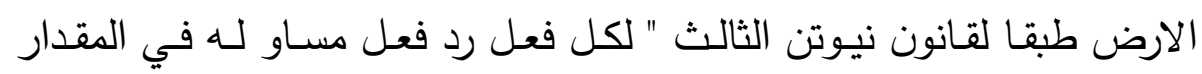

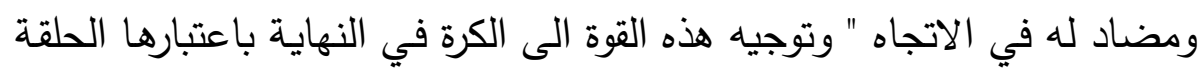

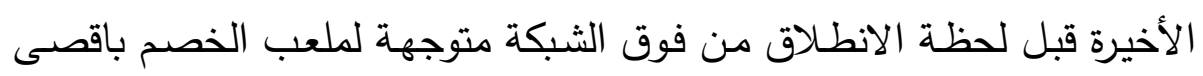
سرعة ممكنة لتصل لملعبه قوية وسريعة مما يزيد من صعوبة ردها.

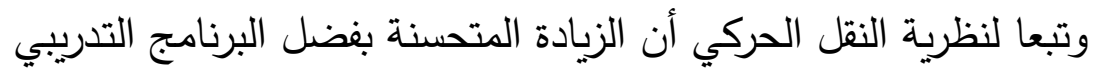

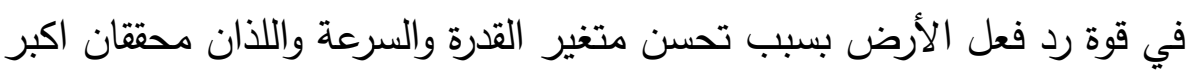

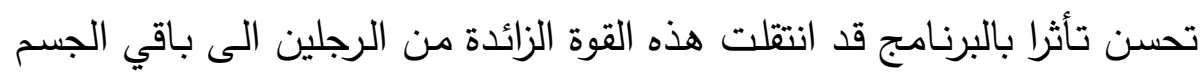

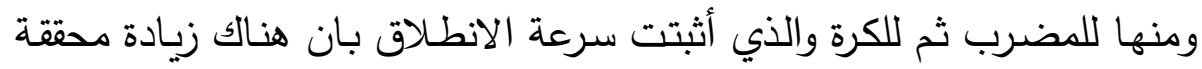

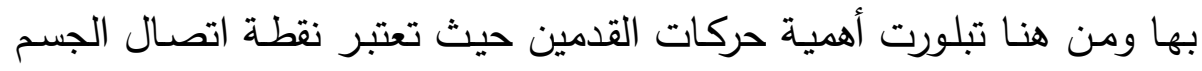

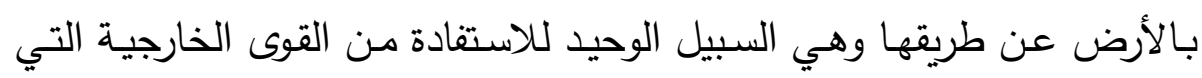
تعمل على تحريك مركز تقل الجسم لتغير كافة اتجاهات.

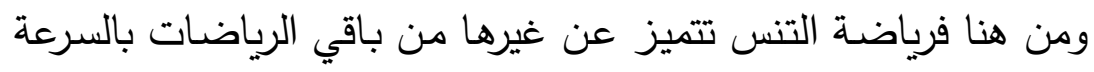

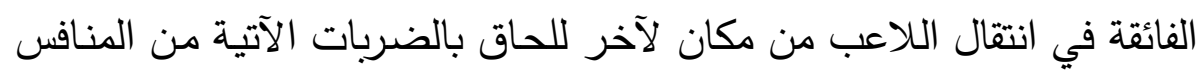


للقيـام بردهـا بكفاءة عاليـة وتكون بحركات القدمين سـواء للجانب بـالجرى أو الزحلقة، أو للامام وللخلف ويتوقف ذللك على مواقف المباراة.

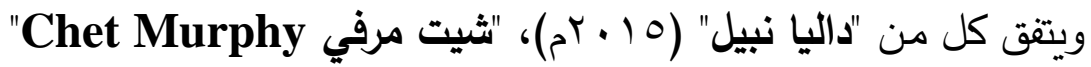

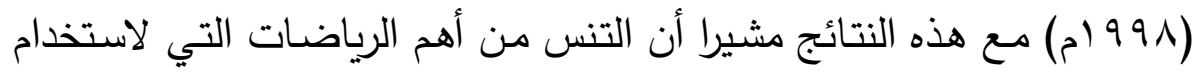
حركات القدمين بها أهميـة عظمسي فاسـتخدام حركات القدمين بشكل مباشـر

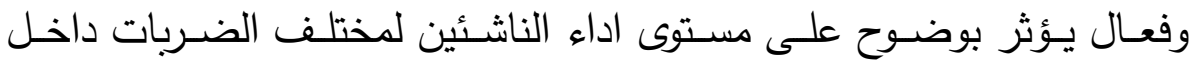

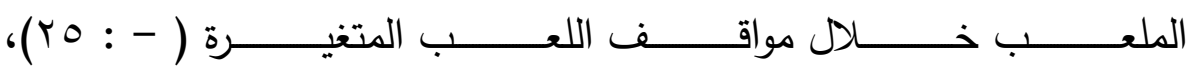

$$
\text { (I (I : }: \leqslant T)
$$

يضـيف "أمسين الخـولي، جمـال الثـافعي" ( ( . . ب) ان معظم حركات

الضـرب لا تحسـن بواسـة مرجحـة المضـرب ولكن بواسـة القدمين لأنهــا

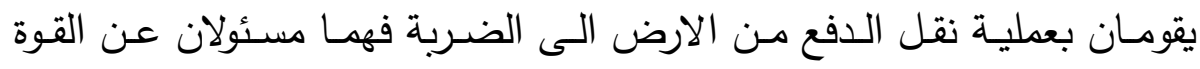

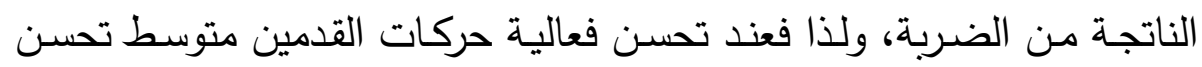

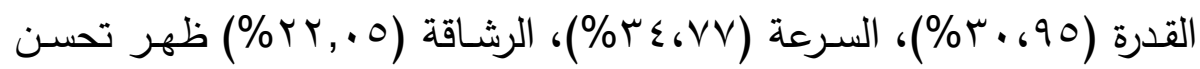

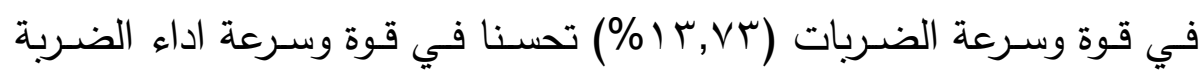
الأرضية الامامية، (1), (1\%) تحسنا في قوة وسرعة اداء الضربة الأرضية

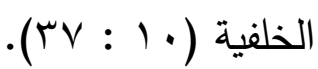
ثالثاً: مراعـاة مبـادئ التدريب العلميـة مـن اختيـار تمرينـات مشـابهة لـلأداء المهاري لحركات القدمين.

مراعاة ان تقوم التمرينات المختارة بتدريب المجموعات العضلية المختلفة وخاصة عضلات الرجلين بهدف تطوير وتحسين سرعة الأداء وتحمله مما أدي لظهور فروق ذات دلالة إحصائيا في متغيرات قيد البحث.

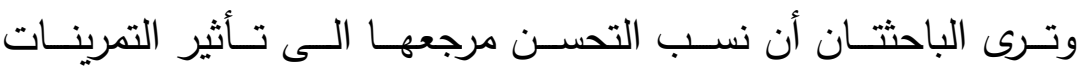
المسـخدمة في البرنـامج التدريبي لتحسـين بعض القـدرات الحركيـة الخاصـة 
بحركات القدمين لناشئي التنس ومـا اشتمل عليه من تدريبات مشابهة للأداء لتحسين المتغيرات قيد البحث.

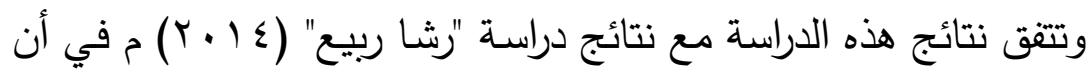

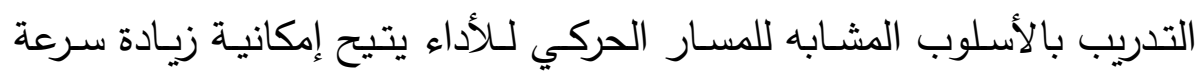

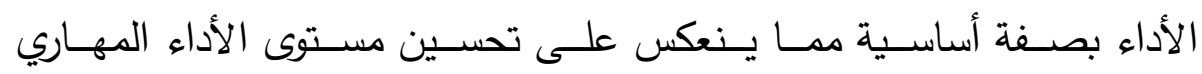
.(9): 17 )

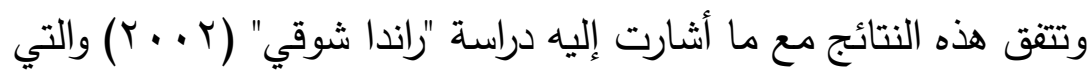

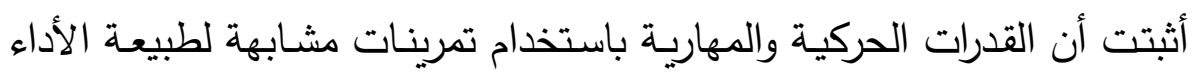
المهاري من خلال المسار الحركي والعمل العضلي تتحسن بصورة كبيرة ضمانا

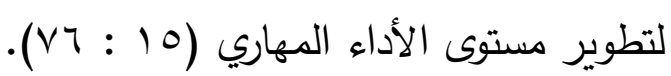

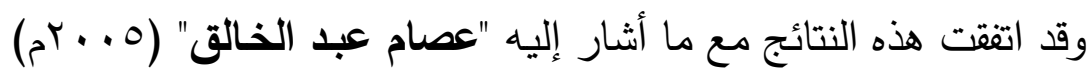

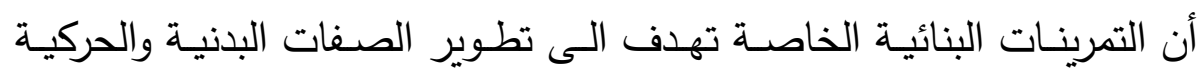

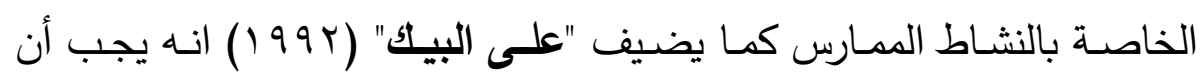
يوجه البرنامج التدريبي للتركيز على تطوير القدرات البدنية والحركية والارتقاء

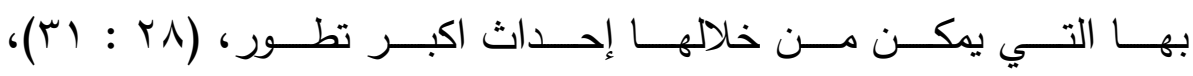
$\cdot(r \wedge: r \cdot)$

وترى الباحثتان أن نسـب التحسـن مرجعها فاعليـة البرنـامج التدريبي

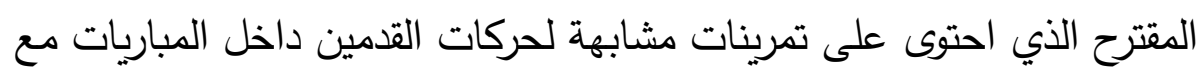

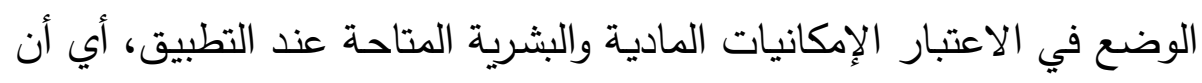

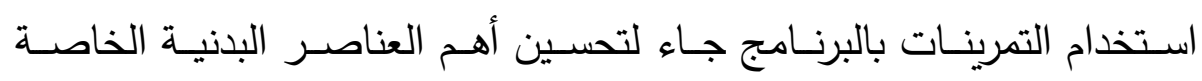
بحركات القدمين لناشئي التنس والتي أثرت بدورها على تحسن في الإنس الاختبارات

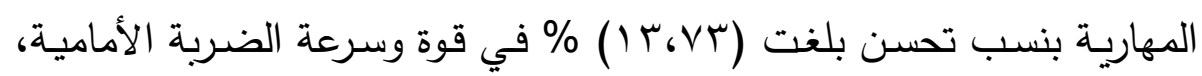

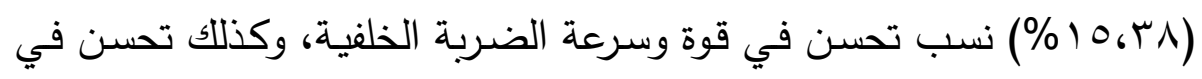

\section{مجلة أسيوط لعلوم وفنون التربية الرياضية}




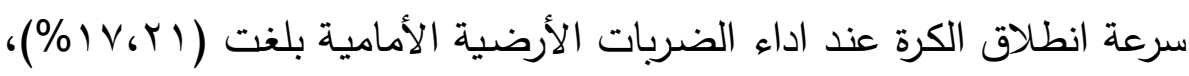

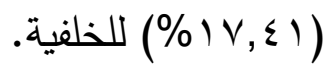

رابعـا" : تقنين حمـل التـريب ( شـدة - حجـم - كثافة ) واختيـار طريقـة التدريب المناسبة، ومراعاة الفروق الفردية لعينة البحث.

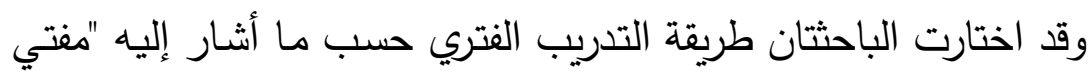
حماد" ( • ( • ( ) م بان من أهداف طريقة التدريب الفتري تطوير السرعة، وهو مـا يفسـر بـان اكبر تحسـن في متغيـرات البحث كـان في اختبـارات السـرعة

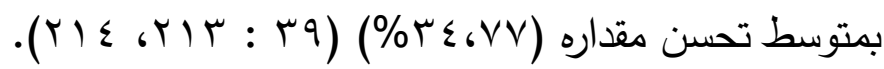

وقد راعت الباحثتان في تخطيط بعض الوحدات التدرببية أن تكون بشدة عالية مستندة الى أن التدريب بشدة عالية يزيد من سرعة استشفاء العضـلات

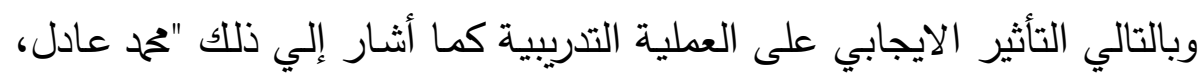

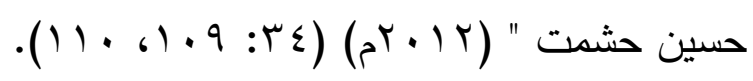

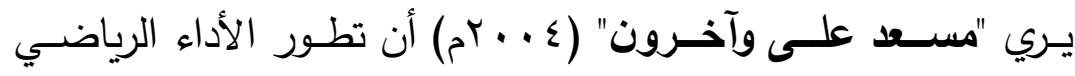
Athletic performance مختلف الأنشطة الرياضية والذي انعكس على تحطيم الأرقام القياسية ما هو إلا هئل

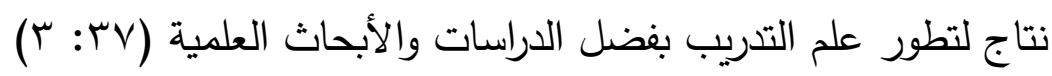

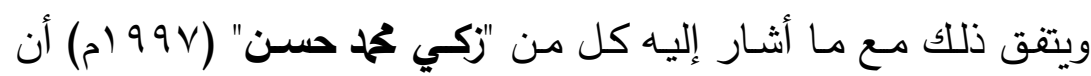
البرامج التدريبية المخططة والموضوعة على أسس علمية تحقق أفضل مستوى التصن

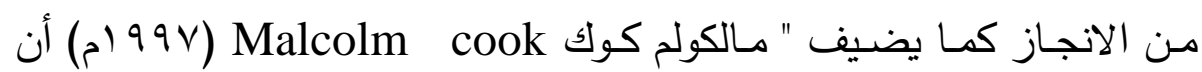
البرامج العلميـة المقنــة والمنظمـة التي تتبع الأسس العلميـة وفق خطـة زمنية وتسلسل منطقي لوحدات التدريب وفقا لأهداف محددة مسبقا تصل لأفضل الأل

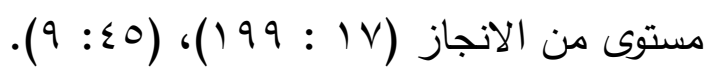


وتؤكد نتائج دراسة "رشا ربيع" (ـ ( • بم) أن التأثير الايجابي للبرنامج

التدريبي المقترح المقنن علميا والتخطيط الجيد لله ومراعاة المبادئ العلمية عند

التطبيق يؤدي بالقطع الى تحسن في المسار الحركي للعضلات العاملة (7 (1: .(^ז

ولقد راعت الباحثتان مبدأ خصوصية التدريب حيث يشير "طحة حسام

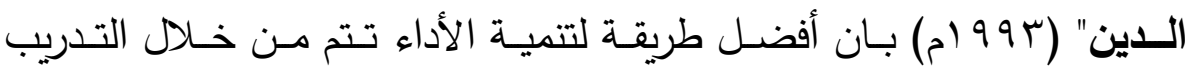

بأسلوب مشابه بدرجة كبيرة من أسلوب المنافسة ذاتها، وكلما كانت التدريبات

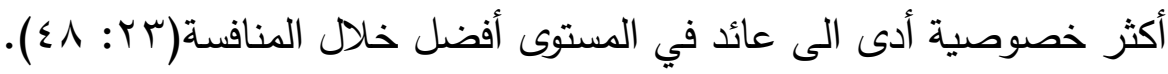

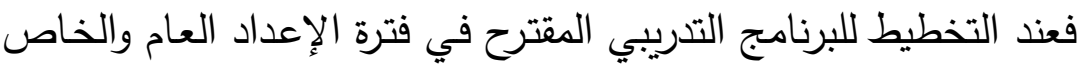
وعند تطبيقه لمدة (• () أسابيع قد راعت الباحثتان وضع أحمال تدريبية متدرجة

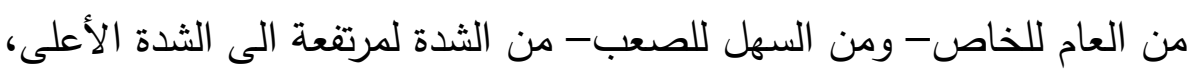

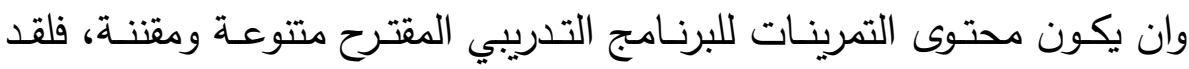

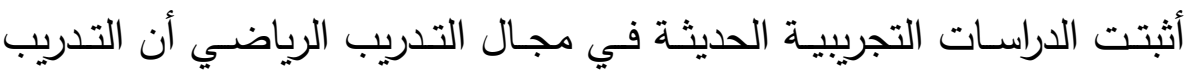

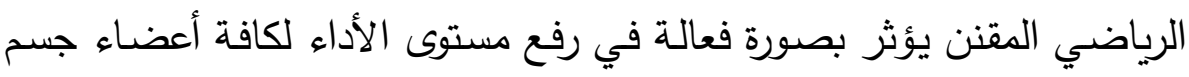

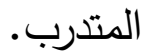

ويرجع التحسن في جميع متغيرات البحث (اختبارات قدرة - سرعة -

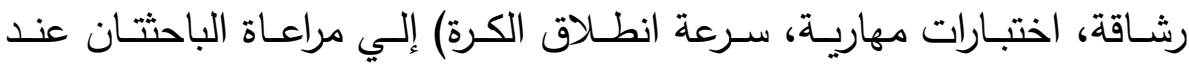

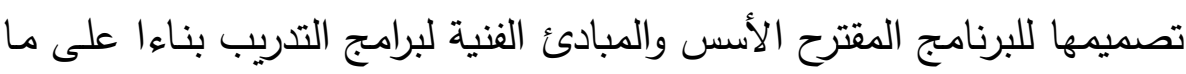

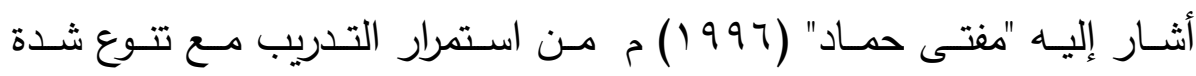

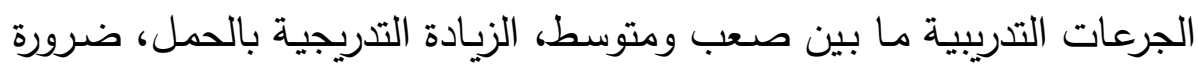

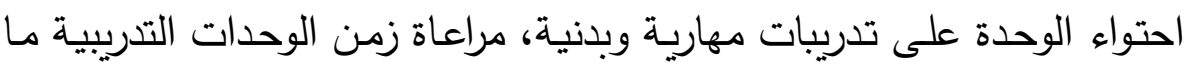

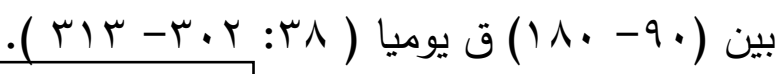


خامساً: مراعاة خصائص المرحلة السنية لعينة البحث وأن تتناسب التمرينات المختارة مع قدرات الناشئ المهارية والبدنية وخصائصه السنية.

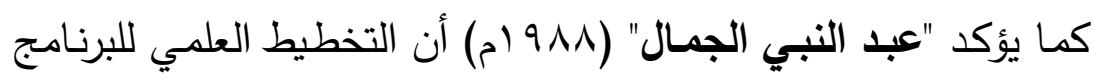

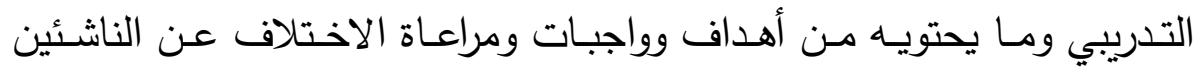

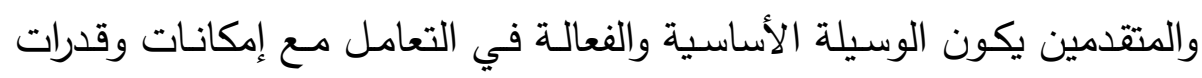

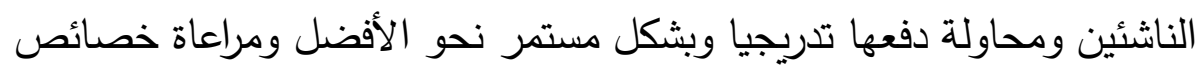
النمو المناسبة لكل مرحلة سنية من خلال رفع المستوى البدني والفني للناشئين

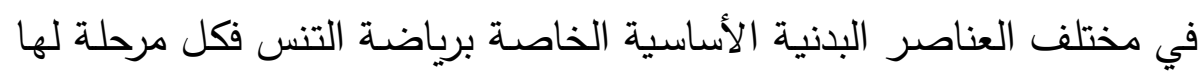

$$
\text { واجباتها وأهدافها ومحتوياتها ( ب ب: 1). }
$$

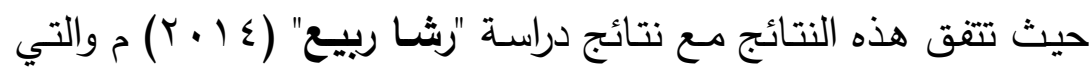

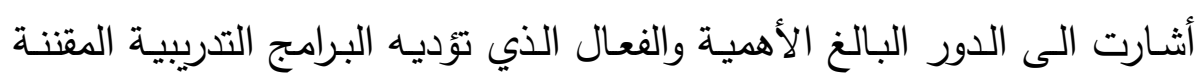

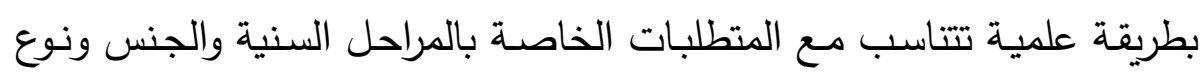

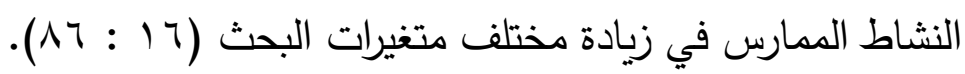
ومرجع التحسن في متغيرات البحث كافة يرجع الى انتظام أفراد العينة

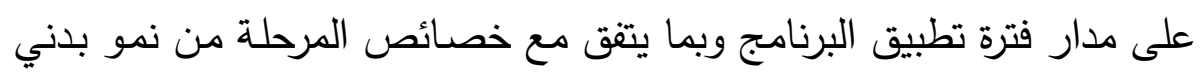

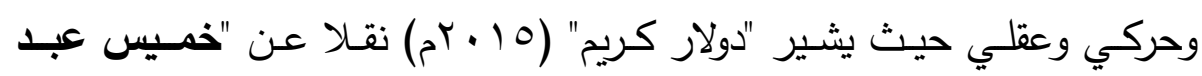

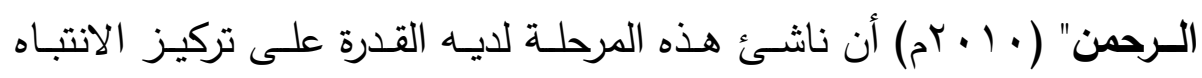

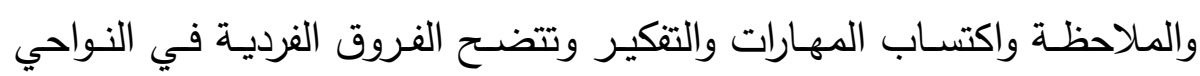
العقلية فهي تعتبر مرحلة إتقان المهارات الحركية وخطط اللعب، ويؤكد أن هذه واته

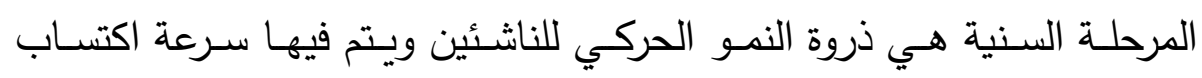

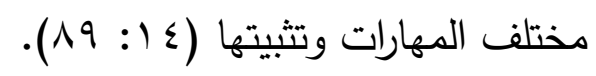

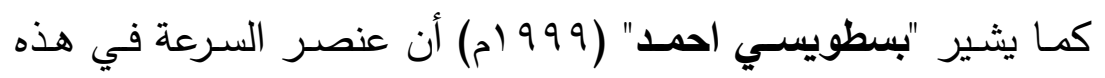

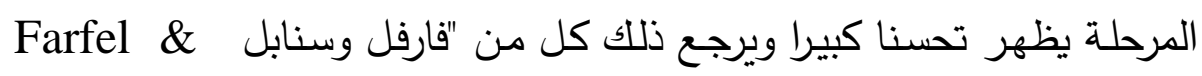


Snaul" بان سبب ذلك يرجع الى النمو والنضـج في العمليات العصبية في

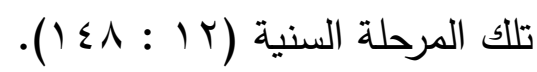

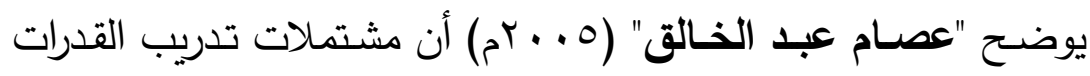

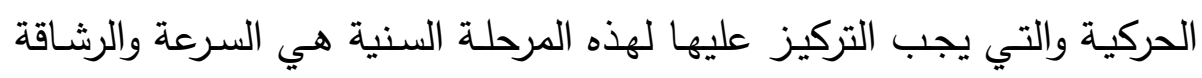

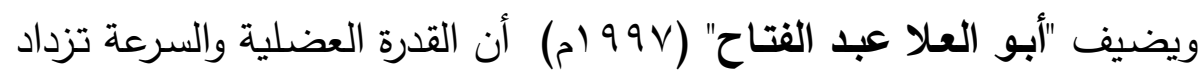

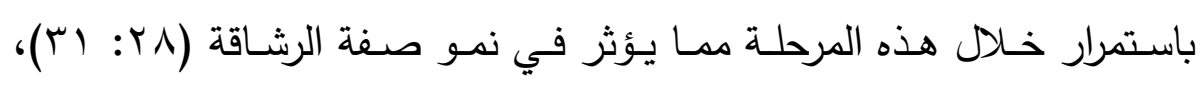
( $110-11 \leq: 1)$

بينما يشير "أسـامة كامسل راتب" (1991) ) م الى أنـه يجب أن يوجـه التدريب في هذه المرحلة السنية لاحداث اكبر تحسن في صفات المات السرعة والقدرة واللاتي يقومن بتحسين صفة الرشاقة إلا أن هذه المرحلة السنية خاصة للـئ للذكور

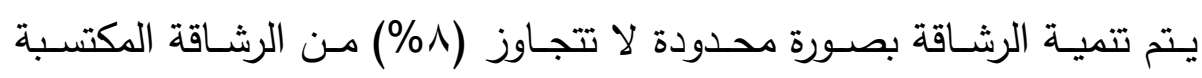

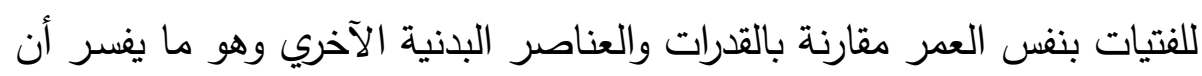

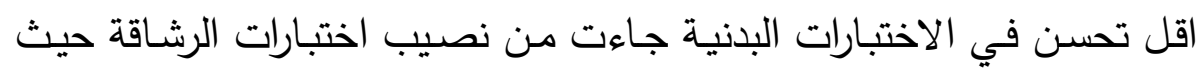

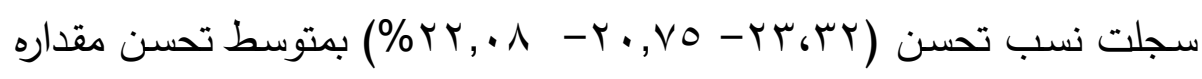

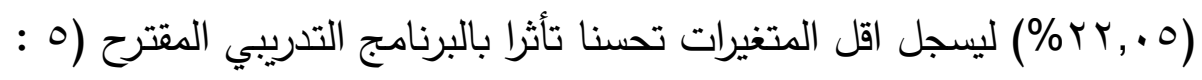
.$(9$.

ومع ذلك فقد كان من الصعب أن تهمل الباحثتان اختيار صفة الرشاقة

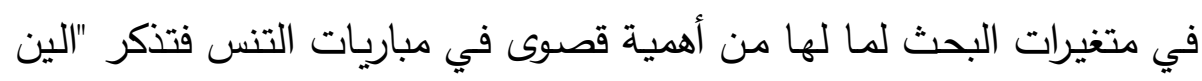

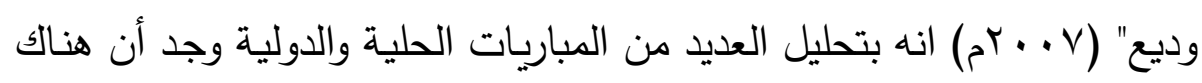

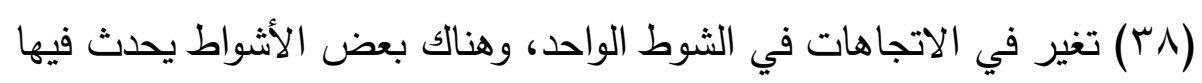

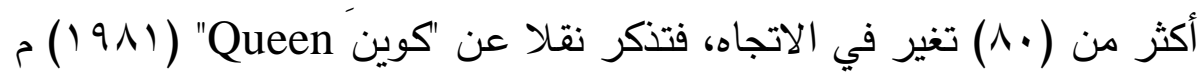

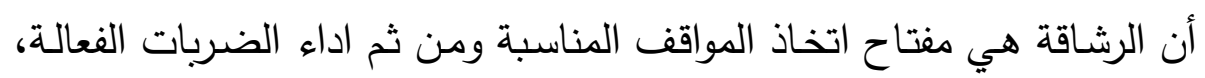

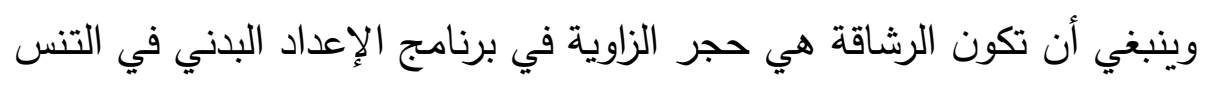
. (109:9) 
وتثير الباحثتان هذا التحسن في القياس البعدي على القبلي الى التأثير الايجابي للبرنامج التدريبي المقترح والمتمثل في التدريب على الرئ الرمال المقنن

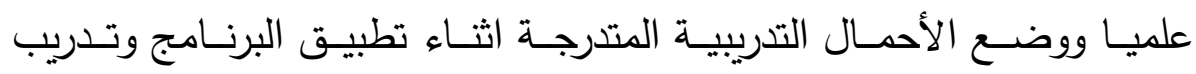

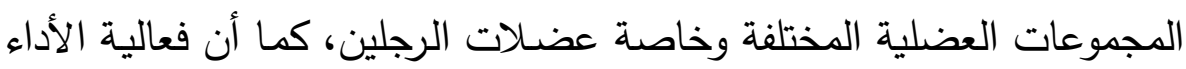

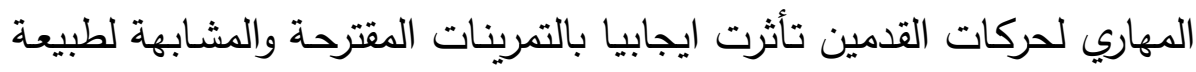

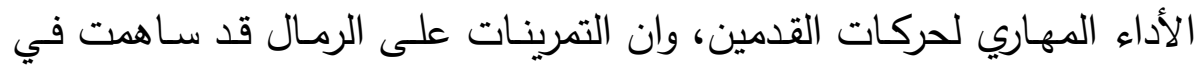
تحسن فعالية حركات القدمين.

وتضيف الباحثتان أن معدل التغير مرجعه الى طبيعة البرنامج التدريبي لتحسين بعض القدرات البدنية الخاصة بحركات القدمين والذي راعت الباحثتان

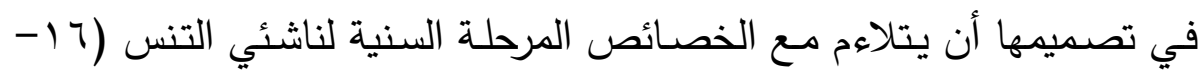
1/) سنة (عينة البحث) وبذلك يكون قد تحقق فرض البحث.

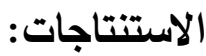

في حدود إجراءات ونتائج البحث تم استتاج أن البرنامج التدريبي المقترح

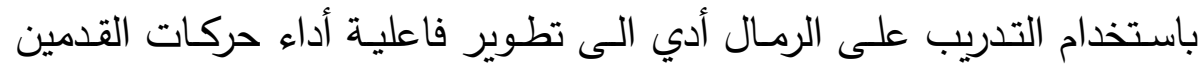

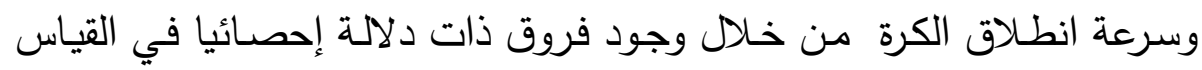

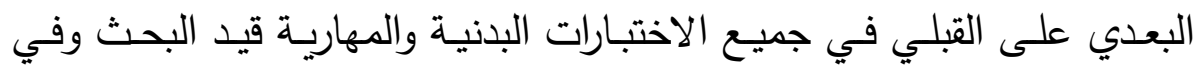

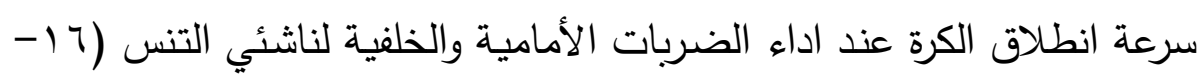
1/ 1 ) سنة حيث بلغت نتائج نسب التحسن كالتالي:

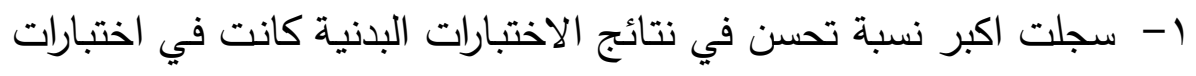

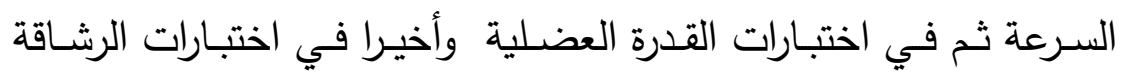

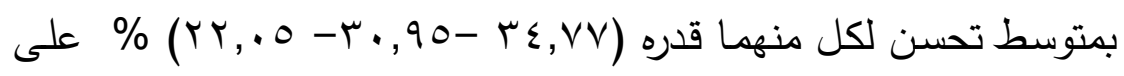

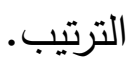

r- سجلت اكبر نسبة تحسن في نتائج الاختبارات المهارية كانت في اختبار

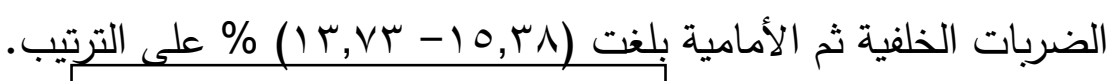

\section{مجلة أسيوط لعلوم وفنون التربية الرياضية}


r- سجلت نسبة التحسن في سرعة انطلاق الكرة عند اداء الضربات الخلفية

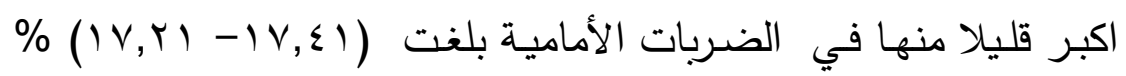
على الترتيب.

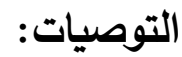

في ضوء ما توصلت إليه الباحثتان من نتائج البحث توصي بما يلي :

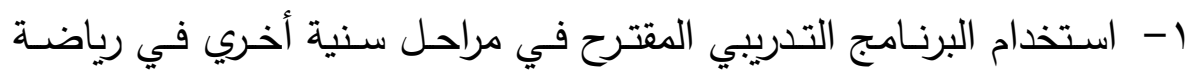
التس.

ץ- عقد دورات تدريبيـة لصـقل مدربي التنس وتـأهيلهم لاسـتخدام تـريبات

$$
\text { (التدريب على الرمال). }
$$

r- الاعتماد على التدريب على الرمال لما لله من قدرات عالية في تحسين التصائ عناصر القدرة العضلية والسرعة بأنواعها.

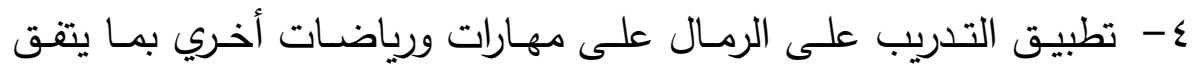
وطبيعة وأهداف الرياضة.

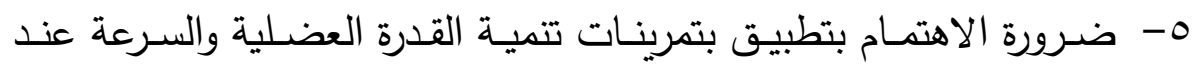

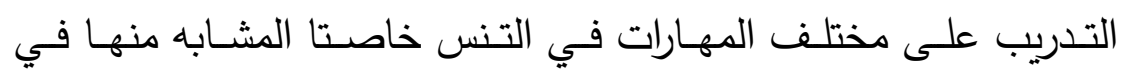
المستخدمة في مهارات اللعبة.

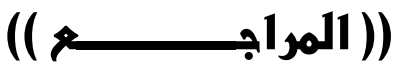

أولاً : المراجم العرببة.

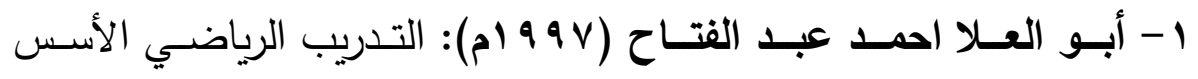
الفسيولوجية، دار الفكر العربي، القاهرة.

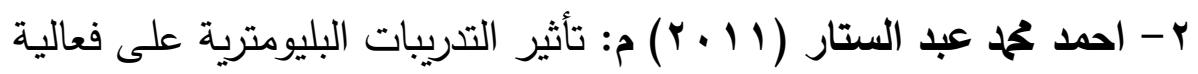

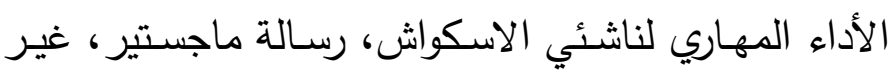
منشورة، كلية التربية الرياضية، جامعة المنصورة. 


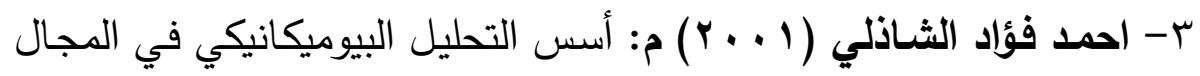

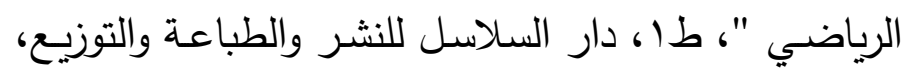

$$
\text { الكويت. }
$$

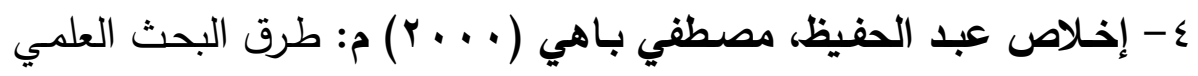

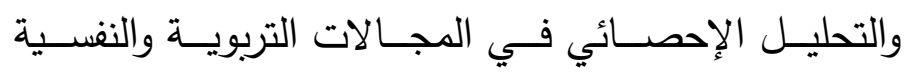
والرياضية، مركز الكتاب للنشر ، القاهرة.

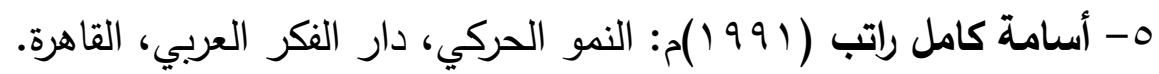

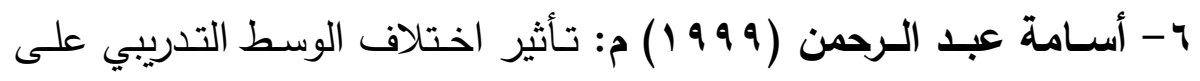

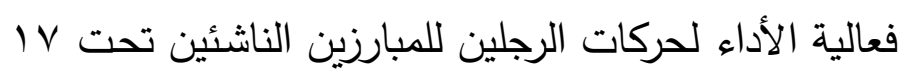

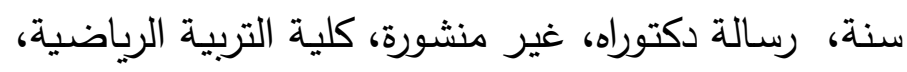
جامعة الإسكندرية.

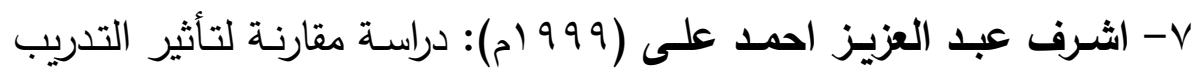

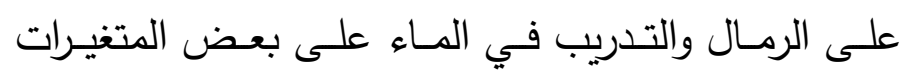

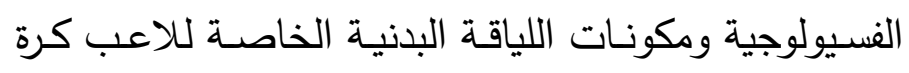

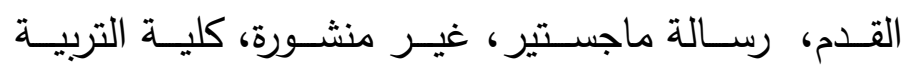
الرياضية، جامعة طنطا.

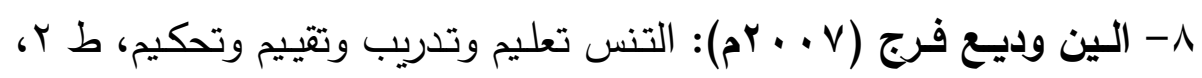
منشأة المعارف، الإسكندرية.

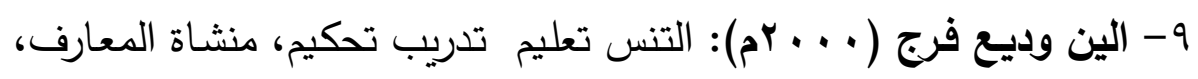

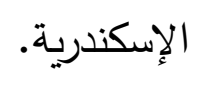

• 1- أمسين أنسور الخـولي، جمـال الـدين الثـافعي (1 . . بم): التنس تاريخ مهارات قواعد اللعب، دار الفكر العربي، القاهرة.

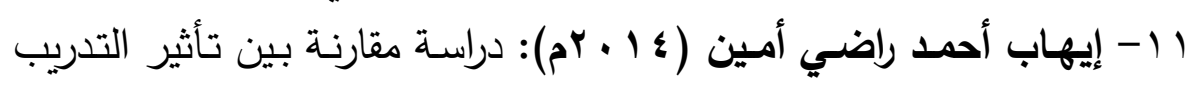

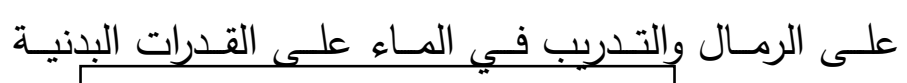

\section{مجلة أسيوط لعلوم وفنون التربية الرياضية}


الخاصـة والمستوى الرقمي لمتسابقي · ا ام حواجز ، رسالة دكتوراه، غير منشورة، كلية التربية الرياضية، جامعة المنيا. r ا - بسطويسي احمـ (999 99 (م): أسس ونظريـات التدريب الرياضسي، دار

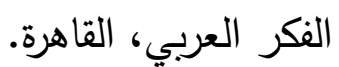

rا - داليا نبيل محمد (0 1 • rم): العاب المضرب (التنس- الاسكواش) إعداد بـدني- تحليـل حركي- خطـوات تعليميـة- تدريبات)، دار المعرفة للطباعة، المنيا.

ع ا - دولار كريم عمر (ع 1 + rم): مستويات معياريـة لبعض القدرات التوافقية لناشئي التسس الأرضي، رسالة ماجستير غير منشورة، كلية التربية الرياضية، جامعة المنصورة.

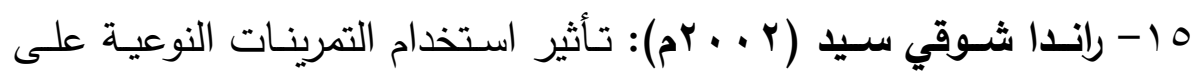
مستوى أداء مهارتي دفع ونطر الكرة في هوكي الميدان، رسالة دكتوراه، غير منشورة، كلية التربية الرياضية للبنات، جامعة الزقازيق.

7 ا - رشا ربيع فهمي على الدين (ع ا ـ rم): تأثير التدريبات اللاهوائية على

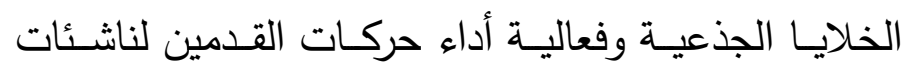

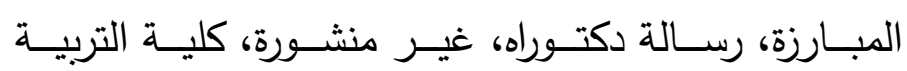
الرياضية، جامعة أسيوط.

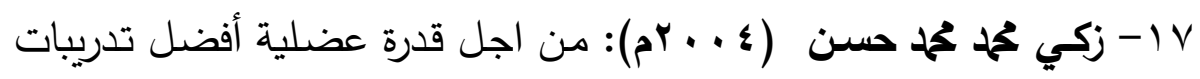

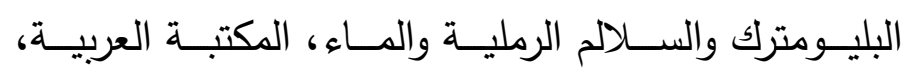
الإسكندرية.

11 - زكي محمد تحمد حسن (99V (م): المدرب الرياضي أسس العمل في مهنة التدريب، منشاة المعارف، الإسكندرية. 
9 1 - سعيد جميل الأثقر (ع + . rم): تأثير تتمية التحمل الخاص على بعض

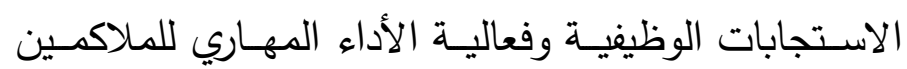
الثـباب، رسـالة ماجسـتير، غيـر منشـورة، كليـة التربيـة الرياضية، جامعة المنصورة. • r - شريف فتحي صالح (0 . . rم): استخدام التدريب العرضي في تطوير القوة العضلية والمرونة وتأثيره على مستوى الأداء المهاري،

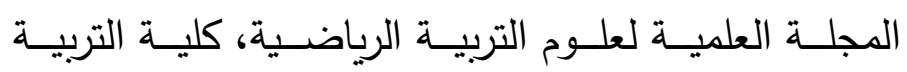
الرياضية، جامعة طنطا، العدد السادس.

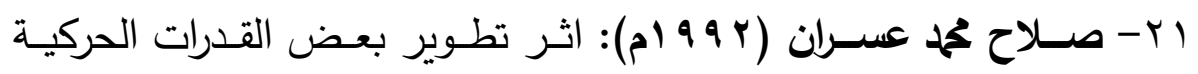
الخاصة على اداء مجموعة حركات الرمي من فوق المقعدة

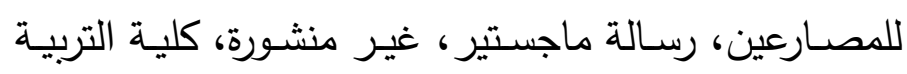
الرياضية، جامعة حلوان.

r - طـارق محمـود عبـ السـلام ( . . . rم): دراسـة تطوير بعضه القدرات

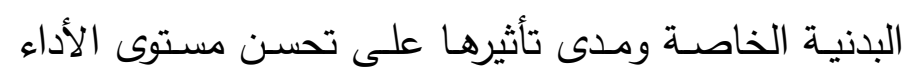
المهاري لناشئي مدارس كرة القدم، رسـالة ماجستير، غير وملاسير منشورة، كلية التربية الرياضية، جامعة الإسكندرية. بr- طلحسة حسـين حسـام الـدين (ب9 9 (م): الأسـس الحركيـة والوظيفيـة للتدريب الرياضي" دار الفكر العربي، القاهرة.

ع ץ- عـادل عبد البصـير على (999 ام): التدريب الرياضسي والتكامل بين النظرة والتطبيق، مركز الكتاب للنشر .

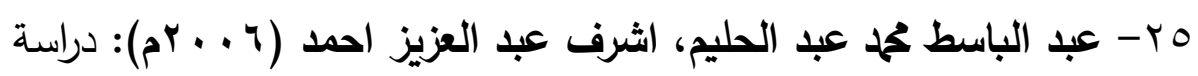

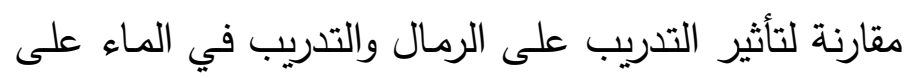

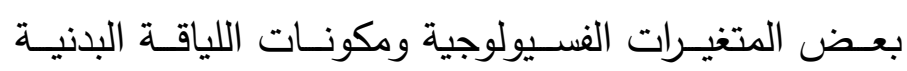
الخاصـة للاعبـي كرة القدم، بحث علمي منشـور ، المجلـة 
العلمية لعلوم التربية البدنية والرياضية، جامعـة المنصسورة، العدد السادس.

جr- عبــ النبـي إسـماعيل الجمـال (9^9 ام): الموسـوعة العربيـة للتنس، الجزء الثاني.

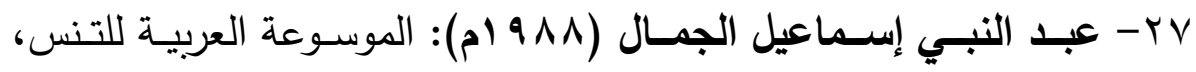
الجزء الأول.

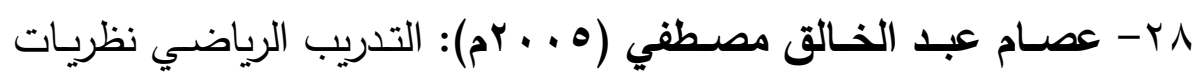
تطبيقات، منشأة المعارف، الإسكندرية.

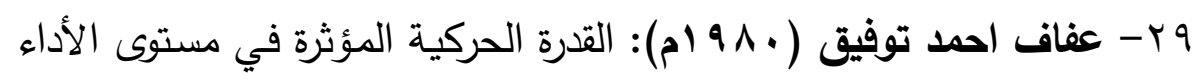

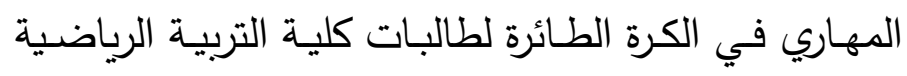

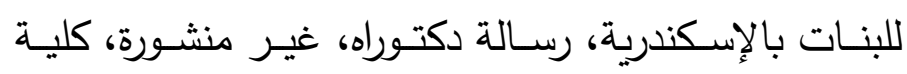
التربية الرياضية، جامعة حلوان.

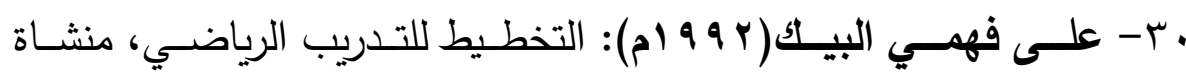
المعارف، الإسكندرية.

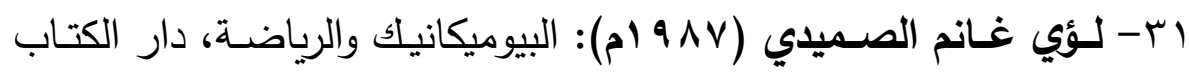

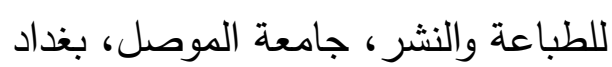

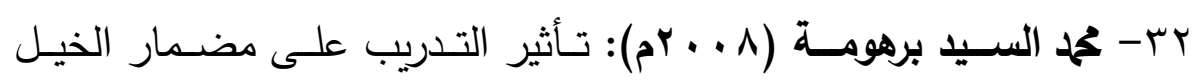

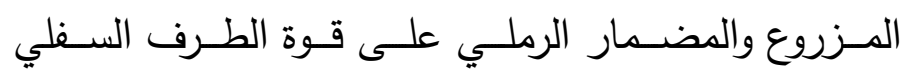

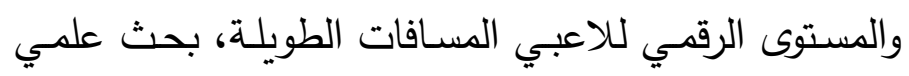

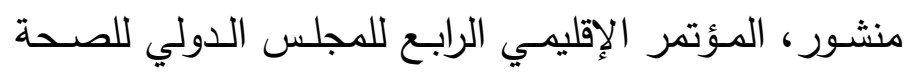

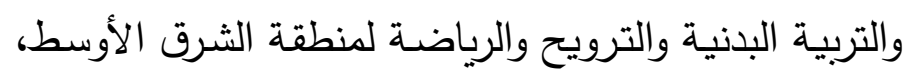
كلية التربية الرياضية للبنين، جامعة الإسكندرية.

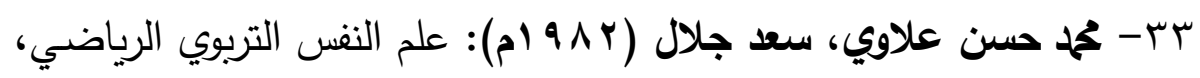

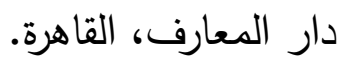




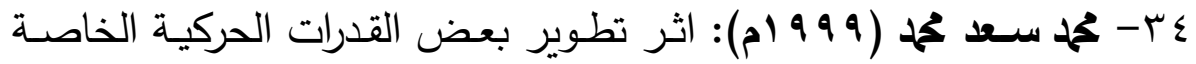

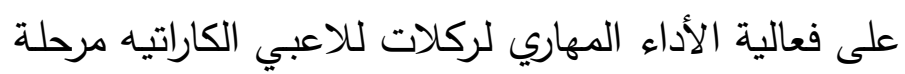

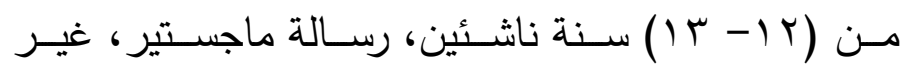
منشورة، كلية التربية الرياضية، جامعة الإسكندرية.

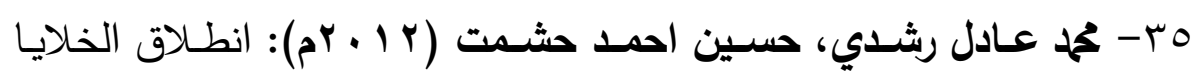
الجذعية في الطب الرياضي"، منشاة المعارف، الإسكندرية. جr- محمد نصر الاين رضوان (9VV) (م)): دراسة عاملية للقدرة الحركية، رسالة دكتوراه، غير منشورة، كلية التربية الرياضية، جامعة دوانه حلوانه

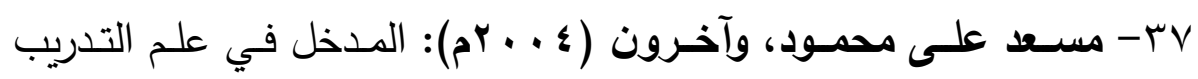
الرياضي، مطبعة دماص، المنصورة.

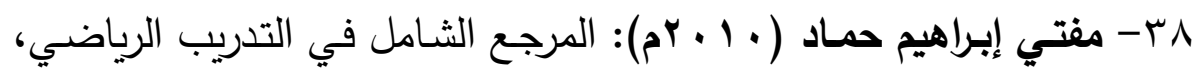
دار الكتاب الحديث، القاهرة.

وب- مفتي إبراهيم حماد (ج 9 ( ام): التدريب الرياضي للجنسين من الطفولة الى المراهقة، دار الفكر العربي، القاهرة.

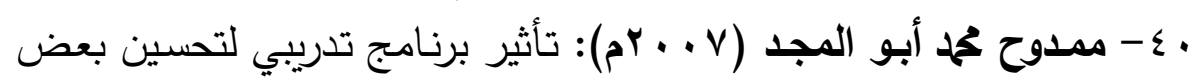

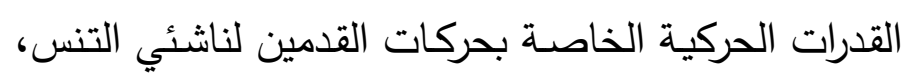

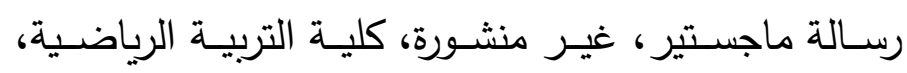

جامعة طنطا.

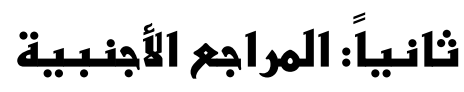

41- Carol Matsuzaki (2004): Tennis fundamentals sport fundamentals series, Library of congress, cataloging Dataa

42- Chet Murphy (1998): Advanced tennis ,W.M.C brown publishers, U S A 
43- Deepak Jain (2001): Coaching Tennis \& Teaching, Hindustan offset printers, New Delhi

44- German Tennis Association (2001): Tennis courses Techniques \& Tactics, Volume 1.

45- Mallcolm cook (1997): Soccer Coaching \& team Management, second edition, London

46- Osama Abdelrrahman (2008): Effect of functional strength training on bone mineral density, power, balance \& performance level of Lunge and fleche for young fencers, statistics and management in sport Nanjing, china, August

47- Ray Collins (1988): Tennis A Practical Learning Guide, Tichenor publishing, P D Box, Bloomungton, Indiana

48- S.Fironi , F Martino \& V Vastagnal (2007): Effect of plyometric training on sand versus grass on muscle soreness, jumping \& sprinting ability in soccer players, school of sport \&exercise science, faculty of medicine and surgery , university of Roma, Italy

49- Tom Ravan (1997): Illustrated teach our self tennis, great Britain in knight books for hodder Stoughton. 
50- United States Pro Tennis Association (2005): Player

Development program, footwork in Modern tennis, Volume 2, No. 4, November.

\section{ثالنظا : المراجم الخاصة بـالانـتـرنتـ}

51- eletawel tennis academy sport. facebook, 20 April , 2013

52- http://aammar.7olm.org/t4-topic

53- -http://www.Standford University.edu/Biomotion research Group /Efficiency in Tennis Footwork ,2006. 